\title{
Geopolitical Configuration of Identities and Learning: Othering through the Institutionalized Categorization of "English Language Learners"
}

\author{
Miwa Aoki Takeuchi* \\ ${ }^{a}$ University of Calgary
}

\begin{abstract}
This study critically examines how the geopolitical configuration of identities, through the medium of the institutionalized label of "English language learners," can shape and constrain localized experiences for learners. An ethnographic video study was conducted in the context of a mathematics unit ("the transforming recess unit") wherein learners conducted surveys, summarized data, and voiced the changes they hoped to see in the elementary school playground. Findings demonstrate both empowering and disempowering ways of mobilizing data and graphs, which are intertwined with multi-layered identities. Interactions in the classroom were nested in macro-level geopolitical configuration of identities that influenced labelled learners' access to becoming "agents of change" who could voice their desired changes in school practices. Categorical and binary frameworks inscribed in mathematics curriculum served as a context for inheritance and reproduction of existing categories through student surveys and graphs. Implications are discussed toward disrupting and transforming taken-for-granted labelling and rigid institutionalized practices through which colonial representation of the Other (Said, 1978) can be coconstructed.
\end{abstract}

Keywords: transforming space; multi-layered identities in learning; elementary mathematics classrooms; "English language learners" or bilinguals; coloniality and identity

\footnotetext{
* Correspondence 2500 University Drive NW Calgary AB Canada T2N1N4, Email: miwa.takeuchi@ucalgary.ca
} 
Who has access to the power to create history anew? This article demonstrates how the geopolitical configuration of identities and co-construction of the Other (Said, 1978) configured through media portrayals and local language policies_-are entangled with learner experiences for those who are institutionally classified as "English language learners (ELLs)." From the lenses of identity, participation, and power, this article describes learner experiences in

"the transforming recess mathematics unit" that amplified care for friendships and fairness on the school playground for some learners. The unit was designed based on the principle of participatory action research in that it encouraged those who were affected most by the particular issues to take the lead in researching those issues (Cammarota \& Fine, 2008; Fine \& Torre, 2004). As this article will demonstrate, students have great insights about what constitutes fair use of the school playground and how they can foster friendships during recess. The pedagogical design created an otherwise-impossible opportunity for many students in an urban elementary school to mobilize mathematics curriculum for the purpose of transforming their recess experiences. Against the backdrop of this "success story," however, quieter voices were not heard, and some students' marginalized identities were further reinforced in the unit. Drawing from ethnographic video research, this article examines the dynamics between multi-layered identities and learner experiences, guided by the overarching research question: How did the multi-layered identities intersect with learner experiences during the transforming recess mathematics unit? Based on the findings, I argue that the opportunities to gain agentive locally constructed identities such as "agents of change" are intertwined with a macro-level and mesolevel geopolitical matrix of power.

\section{On the Institutionalized Label of "English Language Learners" and Mathematics Learning}

The label of "ELLs" in education is a double-edged sword. On the one hand, the institutionalized label of ELLs enables policies that redistribute resources targeting the particular group of students in need. To support the academic success of those students, mathematics teaching resources specifically tailored to ELLs have been published (e.g., Civil \& Turner, 2015; Kersaint et al., 2008). On the other hand, the label of ELLs has been questioned because it overemphasizes the deficits of these students (Civil, 2014; Flores \& Rosa, 2015; García \& Leiva, 
2014; Gutiérrez \& Orellana, 2006). Alternatively, researchers have used terms such as "emergent bilinguals," "bilingual students," and "bilingual mathematics learners" (e.g., Fernandes et al., 2017; García \& Leiva, 2014; Moschkovich, 2007; Zahner \& Moschkovich, 2011). Such reframing can help shape what researchers pay attention to. For example, Fernandes et al. (2017) attended to and demonstrated what bilingual students can exhibit mathematically through multimodal explanations.

The label "ELLs" is still commonly used in school practices and educational policies and therefore it is essential to understand the emic meaning attached to this label, including the learning opportunities that interact with a person labeled as such. De Araujo et al. (2016) pointed out how the implicit belief that ELLs are mathematically deficient and less capable can interfere with teaching because teachers with such beliefs may emphasize basic mathematical facts or procedures rather than conceptual understanding. In Langer-Osuna's (2016) study that involved a learner who was an ELL, social and intellectual forms of authority became linked and shaped the take-up and evaluations of mathematical ideas. How the label of ELLs can influence learner experiences in mathematics classrooms has not yet been fully examined, especially through empirical studies.

There has been a body of research examining the relationships between identities and mathematics learning (e.g., Graven \& Heyd-Metzuyanim, 2019; Hand \& Gresalfi, 2015; Bishop, 2012; Radovic et al., 2018). Among this body of research on identities and mathematics learning, the issue of power has been made salient in some contexts (e.g., Esmonde et al., 2009; Gholson \& Martin, 2014; Leyva, 2016; McGee \& Martin, 2011; Nasir, 2004; Nasir \& de Royston, 2013; Planas \& Civil, 2013; Takeuchi, 2018). For example, Nasir and de Royston (2013) juxtaposed a sociocultural analysis and a sociopolitical analysis of data on identities and learning to demonstrate the value of attention to the intertwinement among race, identity, and power. Esmonde et al. (2009) also presented overt and covert normative discourses (on race, gender, sexuality, and class) in students' narratives about group work in reform-oriented mathematics classrooms. Focusing on the influence of macro-level language status, Planas and Civil (2013) described how linguistic minority students were aware of the status differences among languages and eventually stopped using their home languages, even in the context where languages other 
than the dominant instructional language were accepted. In discussing the influence of macrolevel ideology on race and gender, Gholson and Martin (2014) offered an intersectional analysis on how students' social networks nested in the politics of race and gender shaped who were positioned as good mathematics learners.

Yet, the macro-level geopolitical configuration and colonial matrix of identity has not been fully considered in this body of scholarship on identities and mathematics learning. As an exception, on the colonial politics in learning, Philip et al. (2018) depicted how certain bodies were Othered (Said, 1978) and dehumanized when engineering students were discussing the costs and benefits of drone warfare. In the micro-interaction depicted in Philip et al. (2018), colonial histories surfaced in light of the "calculus of trading between enemy and "civilian' lives" (p. 201). To uncover such colonial histories, Philip and Gupta (2020) call for critical interactional analysis on the co-construction of power, identity, and ideology through which disciplines such as mathematics are also co-constructed as ideological. A theoretical lens involving the geopolitical and colonial matrix of identities is significant especially if we aim to examine a context of learning that is colored by migration and refuge, as was done in this article. In this article, I further the conceptualization and analysis of geopolitical and colonial matrix of identities that interact with other layers of identities and demonstrate how colonial representation of the Other (Said, 1978) come to be co-constructed in the disciplinary practices of mathematics classrooms.

\section{Learning, Multi-layered Identities, and Becoming through Thickening}

In regards to the relationship between identity and learning, Lave and Wenger (1991) maintain that "learning involves the whole person; it implies not only a relation to social communities - it implies becoming a full participant, a member, a kind of person” (p. 53). As McDermott (1993) states, learning happens through "the points of contact available to persons in various social settings [as] we can only learn what is around to be learned" (p. 277). What does this whole person mean? Responding to this question, I consider the wholeness in becoming by bringing forth multi-layered identities interacting with each other (Figure 1). 


\section{Figure 1}

Multi-layered identities

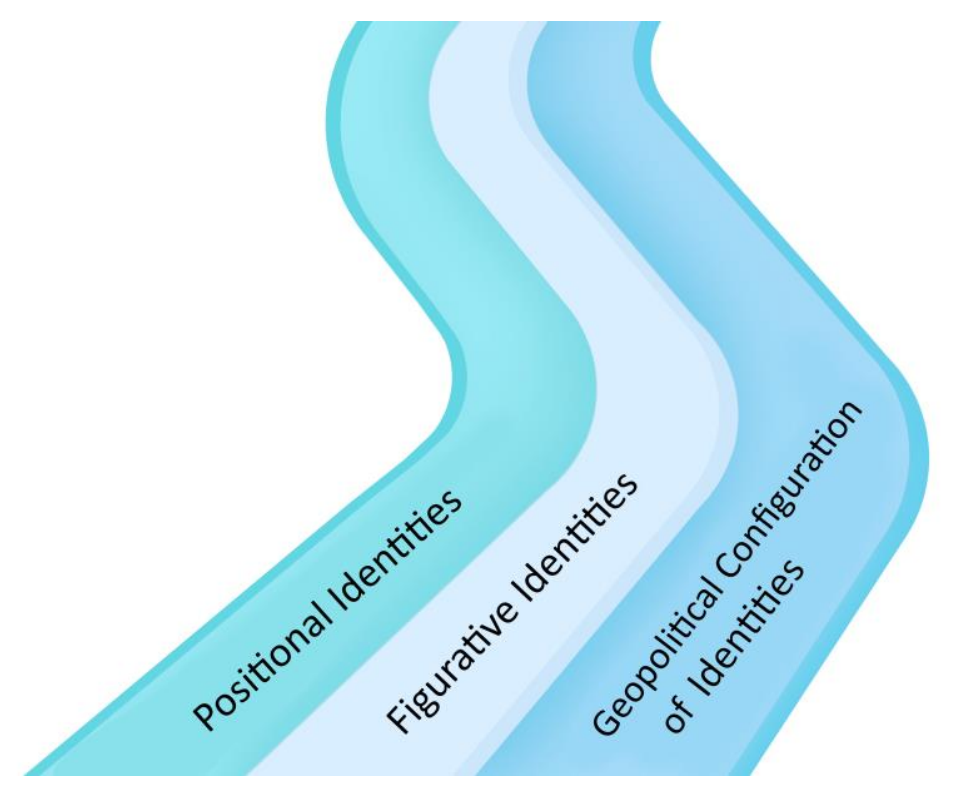

To discuss multi-layered identities, I start with Holland et al.'s (1998) distinction between figurative identities and positional identities. The layer of figurative identities is about "the stories, acts, and characters that make the world a cultural world" (Holland et al., 1998, p. 127). Figurative identities emerge through "signs that evoke storylines or plots among generic characters" (Holland et al., 1998, p. 128). In contrast, the layer of positional identities is about "day-to-day and on-the-ground relations of power, deference and entitlement, social affiliation and distance" and also about negotiations of "access to spaces, activities, genres" (Holland et al., 1998, p. 127-128). By clarifying the distinction between figurative identities and positional identities, Holland et al. (1998) used an analogy: Figurative identities are akin to the semantic facet of speech (e.g., understanding the meaning of "father"), whereas positional identities are comparable to the pragmatic aspect of speech (e.g., understanding relational differences among "papa," "daddy," and "father"). While we can exercise agency to semantically define figurative identities (e.g., by enacting non-normative figurative identities), we can also embody positional 
identities that are assigned to us and eventually enact figurative identities that are more aligned with such positional identities (e.g., by enacting what others expect for a "father").

While Holland et al. (1998) hint that positional identities can include some of the aspects of identities arising from the geopolitical matrix, they do not necessarily make explicit colonization and geopolitical struggles in their conceptualization of identity. As such, adding the layer of the geopolitical configuration of identities can shed light on the geographical, political, and colonial dimensions that shape the formation of subjects, especially the Other, who come to be deprived of being a subject of thoughts and actions, and who come to be deprived of the discursive space to speak and represent (Said, 1978). Furthermore, Said (1978) states that the Other is not only silenced but also often represented with hostility and aggression. The discourse rendered from the colonial matrix (between the East and the West, and between the North and the South) shapes learner identity geographically, politically, and historically. The geopolitical configuration links with epistemology as value and authenticity of knowledge come to be ranked within this colonial matrix of race, region, and language (Mignolo, 2009). Thus, the layer of geopolitical configuration of identities, especially for the Other, becomes salient in the context of learning.

Depending on the interactional configuration, a certain layer of identities can be thickened or laminated through repeated practices. Holland and Leander (2004) used the notion of "thickening" or "lamination" in positioning/identities to discuss "how widely circulating social and cultural resources are (re)produced and articulated with the formation of particular subjectivities" (p. 132). They use McDermott's (1993) study on how the social category of "learning disability" comes to be entangled with a person, as an example of thickening and lamination. In McDermott's study, despite the person's agency to avoid the negative labelling, through the very act of circumventing itself, the person was "acquired" by the social category of learning disability. Similarly, Wortham's (2006) trajectory analysis depicts how the codevelopment of cognitive models and metapragmatic models at different timescales facilitate the interweaving of social identification and academic learning. Wortham's study depicted the interactional process wherein local metapragmatic models or "models of recognizable kinds of people participating in recognizable kinds of interaction" (p. 32) became thickened throughout 
the school year. The thickened layer of identities can create what Goffman (1974) termed as the frame for interactions, the "principles of organization which govern events - at least social ones - and our subjective involvement in them" (p. 10-11). The thickened layer of identity thus frames the way social interactions can unfold.

The lens of multi-layered identities allows us to "see historically" (Gutiérrez, 2016, p. 190). History, as Scribner (1985) reiterated based on Vygotsky's (1978) notion of history in human development, is not subsumed just to general history but also encompasses the history of each society, life history of the individual in society, and history of a particular psychological system. In a similar vein, the meso-level and micro-level figurative identity and positional identity can be intertwined with the macro-level geopolitical configuration of identities. On reproduction or inheritence of colonial history in the micro-scale phenomenon, Ahmed (2007) maintains "that past that is 'behind' our arrival restricts as well as enables human action: if we are shaped by 'what' we come into contact with, then we are also shaped by what we inherit, which de-limits the objects that we might come into contact with" (p. 155). Reproduction of the residues from the past or the generation of the historically anew arises from interactions among these different scales of history. As Gutiérrez and Jurow (2016) stated, "the coordination of past, present, and future-oriented actions and identities sets the conditions for new forms of agency central to realizing possible futures" (p. 567). In this sense, these layers of identity are inextricably woven together; one's becoming emerges from the interactions among these layers of identities. This theoretical lens involving multi-layered identities and the thickening and reproduction of certain layers is key as I focus on the experiences of those who were institutionally classified as "ELLs." While focusing on micro-scale interactions, through the analysis of multi-layered identities, I bring forth historicity in learning.

\section{Methodology}

The methodology for this study was framed by ethnographic research that centralizes the collection of various layers of data toward the thick description of cultural practices to gauge a "stratified hierarchy of meaningful structures" (Geertz, 1973, p. 7) that are produced, perceived, and interpreted in a particular social practice. Through ethnographic work, my aim was to 
capture "complex specificness" (Geertz, 1973, p. 23) for the purpose of "making the familiar strange" (Erickson, 1984, p. 62). Throughout the fieldwork, I paid attention to both what happened as well as what did not happen (Erickson, 1984). My ethnographic fieldwork was accompanied by video recordings to allow me to engage in the repeated and collective viewing of video data (Derry et al., 2010) and to conduct interactional analyses based on the premise that "knowledge and action are fundamentally social in origin, organization, and use and are situated in particular social and material ecologies" (Jordan \& Henderson, 1995, p. 41). From this methodological perspective, the minimum unit of analysis was an interaction or an interactional exchange system, instead of a single utterance.

\section{Setting: Background and School Contexts of the Transforming Recess Unit}

This research took place in a public school situated in a large public school board in Canada, with a population of approximately 450 students representing more than 30 different language groups. Twenty-three percent of the students were born outside Canada, and English was not the language spoken at home for approximately $53 \%$ of the students based on parents' reports (though a teacher told me that many parents hesitated to report to the school that their home language was a language other than English and therefore the percentage would have likely been higher). The school offered language programs for students who had arrived in the last two years and whose first language was not English (in other words, for students who were categorized as "ELLs"). Despite this linguistic diversity and the official bilingual policy of Canada, local language politics place value in English monolingualism (Cummins, 2007). In other words, even while the teacher in this study attempted to interrupt English monolingualism in her own classroom, the broader institutional policy, curriculum, and local language politics privileged English over other languages.

Each regular class in the school consisted of 15-20 students. The school was located in an economically under-resourced neighbourhood of the city and, as part of the school board's equity initiatives, extra funding was provided for teacher professional development and school reform. The teachers in the school, along with other teachers from schools of similar geographical and democratic characteristics, participated in monthly professional development 
seminars on culturally responsive and relevant pedagogy at a local university. I worked closely with Ms. Sally Wilson (here and after, all the participants' names are pseudonyms), one of the teachers who was part of the professional development seminars and visited her classes at least once a week over an academic year. During my visits and during the professional development seminars, we discussed and designed a mathematics unit ("the transforming recess unit") together along with other teachers and facilitators of the professional development seminars.

In this unit, by using concepts set up in the local mathematics curriculum, teachers and students collectively transformed the social terrain of the school playground. Historically, the procedural and receptive aspects of teaching tend to be emphasized more in schools in lower socioeconomic status neighbourhoods (Anyon, 1981; Cummins, 2004). In this context, the teachers and researchers collaborated in hopes of challenging this "pedagogical divide" (Cummins, 2004, p. 4) and co-designed pedagogy with the goal of embracing students' agency in mathematics classrooms. This was achieved by listening to their voices and facilitating their access to codes of power (Delpit, 1988); teachers not only listened to students' opinions on what they would like to learn about their school playground in order to improve the space, but also encouraged all the students to create and conduct surveys, summarize the results, and present their results to other students, teachers, and school administrators (details will be described in the Findings section).

The main lessons for this unit took place for two hours a day, five days a week, for two weeks mainly during the allocated mathematics instructional time; however, because of the interdisciplinary nature of the unit, related lessons and activities were implemented during recess and throughout the semester (e.g., the unit on agents of change in social studies, students' presentations to younger students, and students' presentations at the school council). The theme of this transforming recess unit endured from January to June of the academic year.

\section{Data Sources}

Data collection was conducted in two of Ms. Wilson's mathematics classes (with Grade 4 students, aged between 9 to 10 years old). In the year before I conducted the study in Ms. Wilson's classrooms, I spent one academic year in the same school to get to know teachers, 
students, and the community. I participated in these two classes at least once a week over an academic year and I participated in all the classes relevant to the transforming recess unit. I also participated in monthly professional development seminars that teachers including Ms. Wilson attended at the local university. The research method entailed participant observation with and without video, interviewing, writing researcher journals, and collecting institutional documents.

I collected multiple types of data in order to capture a broader picture of learning: (a) fieldnotes from school visits including recess time, (b) video data from two classrooms (total 45 hours), (c) students' mathematical work and artifacts, (d) fieldnotes and video data from teacher professional development, and (e) school newsletters and other institutional documents (e.g., minutes from the school council). When video recording was not feasible during recess, I relied on fieldnotes. For video data, one video camera with wireless and external microphones was used to capture the interactions during the whole-class discussions. During group work, I focused on the selected focal participants (four students who were identified as newly arrived ELLs according to the above-described criteria and peers who were working with them) and used a video camera and several audio recorders to capture the group interactions around those students. In addition to the classroom data, I conducted interviews with Ms. Wilson three times across the year. I did not set up formal interviews with students, but I occasionally talked with them during recess and while video recording classes. Although I analyzed the whole data set to examine students' learning and identities over an academic year, the main focus of this article is on students' learning during the transforming recess unit and closely analyzing the video data (total 24 hours) during this unit.

\section{Focal Participants}

The analysis depicted in this article focused on the experiences of four students during the transforming recess mathematics unit. Analytically, by bringing forward these four students' cases, I intended to contrast learner experiences that were celebrated and embraced by the teacher with those that were less visible and hidden (in the sense that they were not showcased at school presentations or during the professional development seminars). All the four focal participants were from Ms. Wilson's class. In order to understand the emic meaning of the label, 
interactions surrounding Daniel and Karim, students who were institutionally classified as "ELLs," were analyzed. Daniel was a recently arrived immigrant student from Mexico, spoke Spanish as his first language, but he also demonstrated conversational French proficiency because he had lived in Montreal, a French speaking Canadian city. Karim was a refugee student from Afghanistan and spoke Farsi/Dari as his first language (Karim and his family chose to call their first language, Farsi and therefore I use Farsi in this manuscript). He also lived in refugee camps in Pakistan before coming to Canada. Both Daniel and Karim were classified as "ELLs" based on their assessed English language proficiency and also because they were in Canada for less than two years. Daniel and Karim identified themselves as "boys." Analyzing interactions surrounding Daniel and Karim meant also analyzing utterances by students who closely worked with these students.

I also focused on Cathy and Iris to illustrate learner experiences that were highlighted in the unit by the teacher. Their cases were demonstrated as exemplary by the teacher and by the principal at parent night or at presentations during the professional development seminars. My interviews with the teacher and classroom observations suggested that both Cathy and Iris were positioned in the class as "leaders": they were representatives at the school council and they were the first ones to be asked to help other students by the teacher. They were often working with "ELLs" as suggested by the teacher. Both Cathy and Iris were born in Canada. Cathy said she spoke Punjabi at home and English was her most fluent language. Iris said she spoke English at home, but she said she was also fluent in French. Both Cathy and Iris were tasked to help "ELLs" in the classroom by the teacher. Cathy and Iris identified themselves as "girls."

\section{Analysis}

The inquiry was guided by the overarching research question: How did the three layers of identity (i.e., positional identities, figurative identities, and geopolitical configuration of identities) intersect with learner experiences during the transforming recess mathematics unit? Sub-questions included: 1) How was the agentive figurative identity afforded or not afforded to the focal participants? 2) How did the geopolitical contexts surrounding learners (i.e., local language policy and media portrayal of certain countries) influence moment-by-moment 
positional identities and the agentive figurative identity? 3) How did the three layers of identity influence the ways in which learners mobilized data and graphs?

Analysis and data collection were intertwined throughout my fieldwork. On days of observation, I produced written comprehensive fieldnotes describing the flow of events and duration of events, interactional characteristics within each event (e.g., how the teacher and students interacted with each other), and use of labels among participants (e.g., "agents of change," "English language learners"), based on the memos I took in the field. I also have written analytic memos pertaining to each day of fieldwork.

As a first step of analysis, all the video data was content-logged to capture minute-byminute interactions (Jordan \& Henderson, 1995). Fieldnotes and content logs were analyzed and separately coded line-by-line to inductively find emerging themes for focal analysis (Emerson et al., 2011). One of the central themes was identified around different learning trajectories for students with different labels and geopolitical backgrounds. This initial analysis helped me to find "hot spots - sites of activity for which videotaping promises to be productive" (Jordan \& Henderson, 1995, p. 43) and narrowed down segments of video for fine-grained interactional analysis with video data. Transcription was completed using the conventions suggested by Hepburn and Bolden (2013), as seen in Appendix A.

The following phase of analysis was guided by the framework on different layers of identities (Holland et al., 1998; Said, 1978), described above. For the analysis of the geopolitical configurations of identities, I focused on analyzing interactions surrounding two focal participants (Daniel and Karim) with different geographical and linguistic backgrounds yet both were categorized as "ELLs." An analysis of local politics of language use (Cummins, 2007; García \& Leiva, 2014) and the use of media portrayal as symbolic resources (van Dijk, 1991) were also key parts of the analysis of the geopolitical configuration of Othered identities.

For the analysis of figurative identity, I analyzed identities that can evoke "storylines or plots among generic characters" (Holland et al., 1998, p. 128). Such identities emerge in a figured world, "a socially and culturally constructed realm of interpretation in which particular characters and actors are recognized, significance is assigned to certain acts, and particular outcomes are valued over others" (Holland et al., 1998, p. 52). Focusing on the figured world of 
the transforming recess unit, in this study, I focused on the figurative identity of "agents of change" that evoked certain plots and meaningful acts. The identity of "agents of change" was an emic label that emerged and used in the unit. This analysis was inductively conducted by examining video data, fieldnotes, and classroom artifacts to understand how the figurative identity uniquely emerged during and after the transforming recess unit. The term, "agents of change," and related storylines (e.g., "voicing what students would like to see changed in the school" or "to be part of the process of changing the school") were identified in the teacher's utterances and students' utterances, from repeated viewing of videos and re-reading fieldnotes. To examine how students became "agents of change," I chose cases of Cathy and Iris as illustrative examples. At the same time, through the cases of Daniel and Karim, I also paid attention to the struggles associated with accessing agentive identities, influenced by the institutionalized label that inscribes colonial history.

In the process of repeated video analysis, when micro-politics of hierarchy and difference came to surface, another layer - the layer of positional identities — was added. Segments of video data where the moment-by-moment negotiation of access to movement, language, and space became salient was coded for positional identities. To analyze the positional identities interactionally, where relevant, I referred to the analytical tools including directive/response sequences (Goodwin \& Cekaite, 2013), deixis (Hanks, 2009), and spatial boundaries marked by bodily movement (Kendon, 2010).

\section{Findings}

\section{The Thickening of Agents of Change Identity: The Cases of Cathy and Iris}

While the idea to address social issues that emerge on the school playground came from students, the design of the mathematics unit, the transforming recess unit, developed through collaboration between teachers at the school and researchers at a local university. During the early planning stage of the professional development (PD) seminars, teachers were introduced to the principle of participatory action research as a way to encourage those affected most by an issue to lead a research initiative pertaining to that issue (Cammarota \& Fine, 2008; Fine \& Torre, 2004). The teachers at the school all expressed an interest in knowing more about their 
students' social experiences during recess: how and what they were playing, with whom they were playing, and if there was anything that students wanted to change. The design of the unit started, during one of the PD sessions, when the teachers displayed an interest in involving their students in the process of identifying problems within the school playground. The teachers made connections with the local curriculum on data management (e.g., survey design, graph representation, ratio, and percentage) and mapping (e.g., to map areas of the playground more prone to conflict as seen in Figure 2).

In this unit, all students were given the opportunity to design their surveys individually or with group members who shared common interests. Mathematical topics of frequency, graphs, percentage, and measures of the centre of a distribution of values (mean, mode, and median) were discussed as tools to represent survey findings. The local curriculum for Grade 4 also set an expectation for comparison of variables: "compare similarities and differences between two related sets of data, using a variety of strategies (e.g., by representing the data using double bar graph)." Within the framework of this curriculum expectation, Ms. Wilson encouraged students to compare similarities and differences between two variables, by asking them questions such as: "Think about who you are going to ask. Are you going to ask primaries or juniors? Are you going to ask boys and you're going to ask girls? Decide." When students designed their surveys, some students set up variables of their choice (as seen in the cases of Cathy and Iris); but for other students who did not propose variables on their own, a group member suggested the variables for others (as seen in the case of Daniel) or the teacher suggested potential variables for them (as seen in the case of Karim). Once students completed their surveys, they represented their results with a tally chart, a frequency table, and appropriate graphs (e.g., a double bar graph to compare two variables). 


\section{Figure 2}

Students' Mapping the Areas of Conflict Using a Bird's-Eye View Map of the School Playground

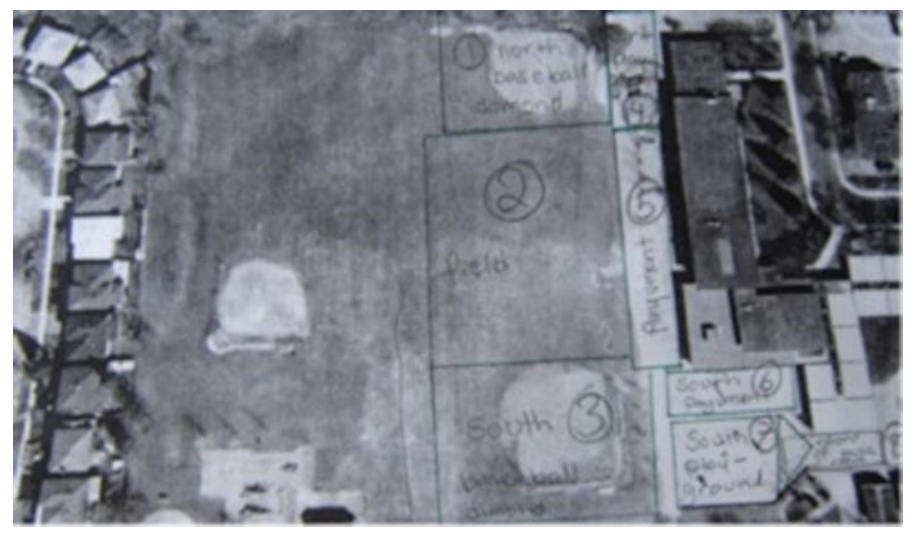

Throughout the transforming recess unit, through Ms. Wilson's interactions with students, the figurative identity of "agents of change" became thickened. During my interview with Ms. Wilson, she reflected on this figurative identity in relation to the vision she had when designing the unit:

I think making an opportunity for the students to actually voice what they would like to see changed in the school and then to actually be part of the process of changing it. Getting away from "let's just complain about this because this doesn't work." I think that's what we do as a society, and kids sort of do it from a young age because they feel powerless. So, just let's complain about it and do nothing about it rather than kids saying, "This is bothering me and I'd like to change it."

She communicated this idea throughout the unit repeatedly both orally and visually — by writing down what she imagined as actions for people who are "agents of change" (see Figure 3 displaying what Ms. Wilson wrote on the blackboard pertaining to the idea of agents of change: "everyone has the responsibility and power to make the world a better place"). When we created a video to present the transforming recess idea to other teachers, Ms. Wilson explained how transforming students into "agents of change" (bolded in the following quote) was one of the central goals of the unit: 
We wanted them to become agents of change and so we thought here's an opportunity for them to become agents of change through their work on issues that they had about recess, and ways to improve recess. (...) Not only were they doing mathematics, but they were empowering themselves. They were learning to communicate their ideas, both visually and orally.

\section{Figure 3}

\section{Classroom Artifact for Figurative Identity of "Agents Of Change"}

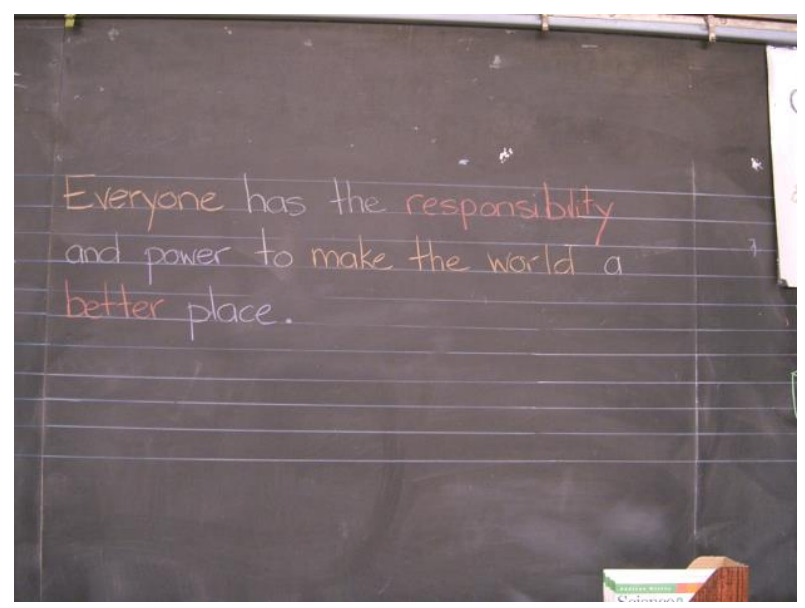

Once all the students completed their surveys, Ms. Wilson invited all students to present their results to students in other grades (as seen in the following quote of teacher talk in the whole class discussion):

Ms. Wilson: Your job, Grade Fours, is to inspire the Grade Twos and Threes, so that they might join you in helping to get your idea up and running. I will assist you, but I'm not going to chase you around and say, "Come on, do it, do it, do it." You've got to take... it's called initiative, where you decide you want to do it and you do it without the teacher asking. Get them excited about making recess better. And I'm hoping that they'll join you.

Throughout the unit, Ms. Wilson continued to ask students, "Who would be a really important person to talk to about these issues?" If students proposed to talk at the school council or to the 
principal, the teacher set up these opportunities for them. Some students accepted the teacher's invitation to present and share their results, but others did not. Cathy and Iris were among those who accepted the teacher's invitation. As follows, I will demonstrate how the figurative identity of agents of change was thickened through such opportunities to interact with the audience. This analysis is later contrasted with experiences by Daniel and Karim who were labelled as "ELLs."

\section{Using the Power of Number to Become Agents of Change}

Cathy wondered if people at the school thought the playground was used fairly during recess and decided to conduct a survey. The school had a policy in which it allocated a different space and time to play in the playground for primary grades (Grades 1-3) and junior grades (Grades 4-5). Cathy created a survey listing three options for the structure of recess and playground access: "a) should we all be able to play together? b) should the north be only for primary and the south for only junior? and c) morning recess, junior go to south while primary go to north playgrounds, afternoon recess we swap" (see Figure 4). She asked both teachers and students and summarized her results with a double bar graph to compare teachers' responses and students' responses (please see Figure 4 right). The following interactions in Excerpt 1 between the teacher and Cathy show how Cathy interpreted her results and intended to communicate her results to the school principal to effect change on school policy in the playground. 


\section{Figure 4}

\section{Cathy's Tally Chart and Survey Results with a Bar Graph}
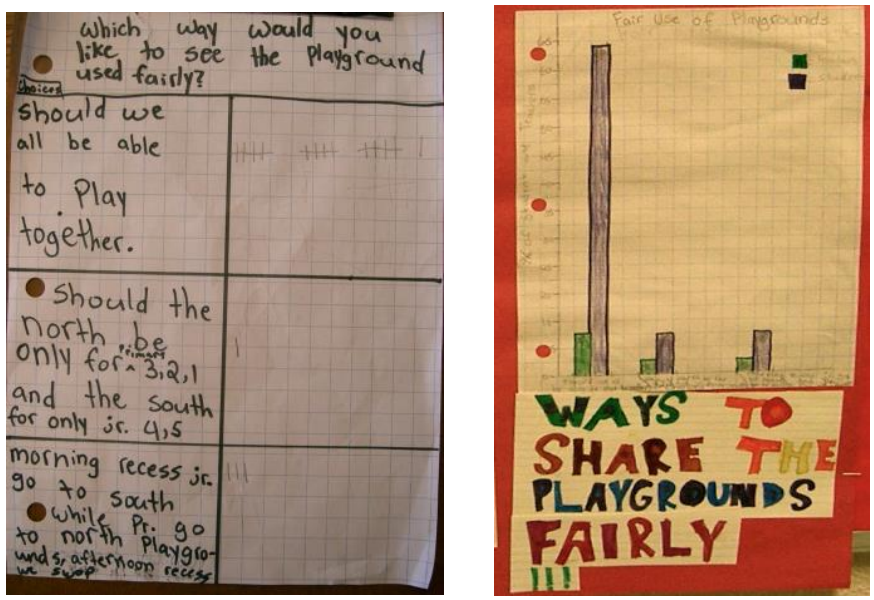

\section{Excerpt 1}

\begin{tabular}{|c|c|c|c|}
\hline 1 & $00: 00$ & Cathy: & $\begin{array}{l}\text { ((Cathy is reading aloud from the conclusion } \\
\text { she has written)) } \\
\text { I have learned that students like to play } \\
\text { altogether. I think we should let everyone play } \\
\text { together and see how it goes. If lots of kids } \\
\text { get hurt then we can change it, hm, because } \\
\text { Grade Fives might not be aware about the Grade } \\
\text { Ones and the younger grades? So if it does work } \\
\text { we might be able to play together. We also } \\
\text { learned that (.) I also learned that teachers } \\
\text { would like students to all play together. }\end{array}$ \\
\hline 2 & $00: 23$ & Ms. Wilson: & $\begin{array}{l}\text { Okay, a:nd what are you going to do with this } \\
\text { data? Is there anything else you want to find } \\
\text { out? }\end{array}$ \\
\hline 3 & $00: 24$ & Cathy: & Hmmmmm \\
\hline 4 & $00: 26$ & Ms. Wilson: & So who are you going to present this data to?= \\
\hline 5 & $00: 26$ & Cathy: & $=$ The principal. \\
\hline 6 & $00: 27$ & Ms. Wilson: & The principal? Okay. \\
\hline
\end{tabular}

In Excerpt 1, Cathy and the teacher are discussing data collected by Cathy (seen in Figure 4). This exchange depicts how the teacher was encouraging application of the data, as seen in her questions: "what are you going to do with this data?" (utterance 2) and "who are you going to 
present this data to?" (utterance 4). As Cathy proposed to show the data to the principal (in utterance 5), the teacher encouraged Cathy to prepare for the presentation. Excerpt 2 follows Excerpt 1 and shows how Cathy's survey results were used as a tool to convince Ms. Wilson (who had an opposing view) to let all the students play together, pending safety concerns. In Excerpt 2, Cathy challenged the teacher's view by showing Ms. Wilson her graph (utterance 3), and Ms. Wilson, with some hesitation (utterances 2 and 6), agreed that they could try Cathy's idea of letting all the students play together (utterance 6).

\section{Excerpt 2}

\begin{tabular}{|c|c|c|c|}
\hline 1 & $00: 00$ & Cathy: & $\begin{array}{l}\text { Ms. Wilson, when I show this to the principals, } \\
\text { if they saw teachers' opinion, would that make } \\
\text { it stronger than only students? }\end{array}$ \\
\hline 2 & $00: 10$ & Ms. Wilson: & $\begin{array}{l}\text { No, not necessarily. I mean, teachers have } \\
\text { different perspectives. We understand ah (5.0) } \\
\text { We have ah (1.0) like kids just think about } \\
\text { fairness as in what they want, you know? But we } \\
\text { have a, we look at things with safety lens, } \\
\text { safety goggles on? We see things through safety } \\
\text { lens and control safety. Like what I said, do I } \\
\text { really want Grade Ones and Fives playing } \\
\text { together on a playground? No way. ((Ms. Wilson } \\
\text { is shaking her head))= }\end{array}$ \\
\hline 3 & $00: 31$ & Cathy: & $\begin{array}{l}\text { =But a lot of teachers think we should all play } \\
\text { together. ((Cathy is showing her graph to Ms. } \\
\text { Wilson)) }\end{array}$ \\
\hline 4 & $00: 34$ & Ms. Wilson: & $\begin{array}{l}\text { That's awesome. That's great then. But that's } \\
\text { how I feel, [right? }\end{array}$ \\
\hline 5 & $00: 38$ & Cathy: & [uh-huh \\
\hline 6 & $00: 38$ & Ms. Wilson: & $\begin{array}{l}\text { So: if the teachers, you know, I mean, it's, we } \\
\text { could try. }\end{array}$ \\
\hline 7 & $00: 41$ & Cathy: & Because we used to all play together. \\
\hline
\end{tabular}

After this exchange, Cathy took up the opportunity to present her data to the principal. Cathy presented the poster she made (Figure 4) to an audience (Grade 2 and Grade 3 students and teachers other than Ms. Wilson) and highlighted the option most students and teachers hoped for (i.e., changing the current playground policy and letting students from all grades play together during recess). The following is what Cathy said to her audience: 
We should all play together because that's technically what got the most, that was what everyone wanted. Like the teachers also wanted everyone to play together and so did the students, so that's why I think we should give that a shot.

Similar to Cathy, Iris also used her data to plan out the actions that they wanted to implement. Iris, together with her peer, Jennifer, led a project about students' favourite recess activities. The goal of this project was explained to Grade 2 and Grade 3 students by Iris as follows:

We think that some new kids that come to the school and some kids at the school, they don't have really anybody to play with. Or they have nothing to do outside. So if we have organized games outside, they'll have at least something to do, instead of wasting their recess just walking around in circles.

Their project was based on their everyday experience of observing students who did not have any friends to play with during recess. The school had a high percentage of newly arrived immigrant and refugee students who moved schools in the middle of the year. In this context, as Iris said in the above quote, she identified a problem: "some new kids that come to the school and some kids at the school, they don't have really anybody to play with." Iris created the survey toward the goal of organizing games in the playground to invite these students who did not have friends and for the goal of fostering friendships during recess; she needed to know the types of games that were favoured by students (see Figure 5). In her presentation to Grade 2 and Grade 3 students and other teachers, Iris discussed her next step:

"Others" was our biggest hit. As you can see, for primaries, twenty-four, about twenty-four kids maybe. And primaries, I mean, juniors, it's all the way up here. Maybe forty-four, fortythree, forty-five kids, which we found very surprising because I think we didn't put "others" under big population. We said "ball games" and "pavement games," we thought was going to be a big hit. But obviously, you can see that "others" was just humungous. And we have some next steps, actually. We are going to continue on with this survey. (...) And we're actually going to make another one. We're thinking that we're going to go back out with another survey asking the juniors and primaries, some of the primaries, what things would you like to go under "others"? 
In the same presentation, talking to Grade 2 and Grade 3 students, Iris invited them to join her project:

If we convince Ms. Cohen (the principal), we would like, we'd like some volunteers like you guys to come out. 'cause we can't manage rampaging kids, you know what I mean? (...) If you would like to help out with organized games at recess in a month or so or in a couple of weeks if we get her convinced, you'd be free to. Just come up to us at recess.

\section{Figure 5}

Iris's Survey Results with a Double Bar Graph.

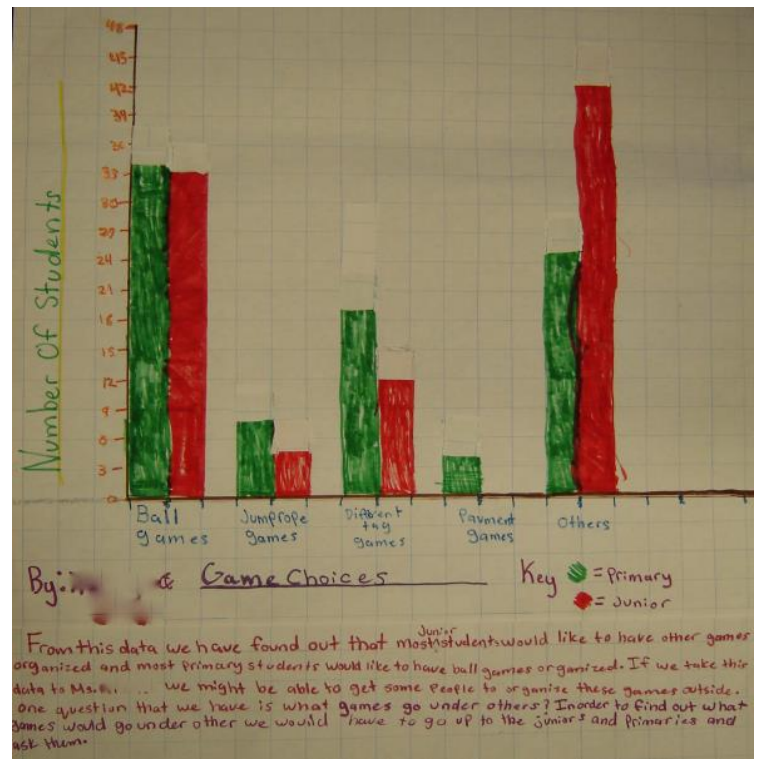

Iris and Cathy made a similar presentation at a school council meeting, to the broader school community that included a presentation to the principal. Their suggestions were taken up by the council and were represented in the list of action items written up in the minutes of the meeting:

1. Having more activities outside for students who have nothing to do. 
2. Asking students to organize games.

3. Making sure the playground is used fairly.

7. Have Peace Leaders.

Later in the year, I observed Iris and Cathy being Peace Leaders who promoted safe and equal use of playground during recess, an idea that was presented at the council meeting. They also became Play Leaders who organized activities that encouraged more students to play together. For Iris and Cathy, their "leader" identities were thickened through the transforming recess unit and they became "agents of change" as they used surveys, data, numbers, and graphs to convince others, including teachers.

\section{The Thickening of "English Language Learners" Identity: The Cases of Daniel and Karim}

The following two sections focus on the experiences of Daniel and Karim, the students who were identified as "ELLs." Throughout the analysis, I will depict the thickened layer of identities and the learning opportunities for Daniel (and Iris, in the interactions with Daniel) and Karim.

\section{From a Multilingual to an English Language Learner: Difficulty in Accessing Opportunities}

\section{to Apply Data to "Larger Scale Application"}

In this section, I present Daniel's experiences during the transforming recess unit, which illustrate how local language politics became intertwined with positional identities and figurative identities, and how the thickened identity linkage shaped a learner's becoming. For group work, Ms. Wilson placed Daniel with Iris and Jennifer, who spoke French and Spanish respectively. This grouping created the opportunity for Daniel to use his first language (Spanish) and second language (French) and created a context wherein he had the potential to continue to be positioned as a multilingual speaker during peer interaction. Instead, however, Daniel was positioned as an ELL who needed support and help from others rather than as an active participant in the project 
(as demonstrated in the following interactions). Excerpt 3 is taken from a class wherein students brainstormed survey questions based on their issues of interest during recess.

In Excerpt 3, students were given post-it notes to jot down ideas and each person was asked to read one idea at a time from these notes. This learning context, along with the teacher's facilitation, allowed conversational turns to be distributed equally and everyone in the small group received a chance to share their ideas without interruptions. Ms. Wilson encouraged Daniel to write his ideas in Spanish on the post-it notes. Because there was another student who could speak Spanish, Daniel's ideas were translated from Spanish to English and thus his ideas were understood by the teacher and other students. In the interaction, Ms. Wilson used French, which is another language that Daniel spoke, when she praised Daniel's answer by inserting a short phrase in French (e.g., "très bien") into her utterance (utterance 5). In this short interaction, Daniel came to be an active participant through the use of Spanish, French, and English. This interaction illustrates the practice of "translanguaging" (García \& Leiva, 2014, p. 204), which is characterized as a fluid discursive space where new languaging realities emerge from the interactions among multiple languages. Not only were multiple languages (Spanish, French, and English) present, but meaning making through gestures was also a significant part of the interactions (utterances 11 and 12 in Excerpt 3).

\section{Excerpt 3}

\begin{tabular}{|c|c|c|c|}
\hline & & & $\begin{array}{l}\text { ((Students are sitting as a small group. On } \\
\text { their desk, they put post-it notes. The teacher } \\
\text { is stopping by at Daniel's group. One student is } \\
\text { sharing one idea written on a post-it note)) }\end{array}$ \\
\hline 1 & $00: 00$ & Teacher & Daniel? \\
\hline 2 & $00: 04$ & Daniel & $\begin{array}{l}\text { ¿Por qué los niños no juegan todos juntos en el } \\
\text { recreo? }\end{array}$ \\
\hline 3 & $00: 10$ & Jennifer & $\begin{array}{l}\text { Why do }(0.2) \text { why don't all the kids play } \\
\text { together at recess. }\end{array}$ \\
\hline 4 & $00: 17$ & Daniel & $\begin{array}{l}\text { Porque solo un día para los niños pequeños y } \\
\text { otro los grandes. }\end{array}$ \\
\hline 5 & $00: 20$ & Teacher & Good questions Daniel. Daniel très bien. \\
\hline & & & $\begin{array}{l}\text { ((Three rounds of student introducing their } \\
\text { questions passed)) }\end{array}$ \\
\hline 6 & $03: 04$ & Teacher & Okay. All right. Good. Daniel has one more. \\
\hline 7 & $03: 13$ & Daniel & ¿Por qué los niños no pueden jugar en el hielo? \\
\hline
\end{tabular}




\begin{tabular}{|c|c|c|c|}
\hline 8 & $03: 16$ & Jennifer & Why can't we be on the ice? \\
\hline 9 & $03: 21$ & Teacher & Oh (2.0) Because they could get hurt. \\
\hline 10 & $03: 30$ & Jennifer & (7.0) How do you say that in Spanish? \\
\hline 11 & $03: 34$ & Teacher & $\begin{array}{l}\text { Ouch. Ouch. ('She performs to hit her arm with } \\
\text { her hand and makes a facial expression with } \\
\text { frown)) That's why. }\end{array}$ \\
\hline 12 & $03: 35$ & Oliver & Oh: ((He performs to slip on the floor)) \\
\hline 13 & $03: 40$ & Teacher & $\begin{array}{l}\text { Yes and ouch you can't walk right? That's why. } \\
\text { You get hurt. You might get hurt. }\end{array}$ \\
\hline
\end{tabular}

However, the positioning of Daniel as a multilingual did not endure throughout the transforming recess unit. Reflecting on English monolingualism in the broader school context, during peer interaction, Iris and Jennifer often spoke English to communicate with each other. They did this, for example, while working on a project investigating students' favourite activities in order to organize activities during recess and, eventually, Daniel was left out of the discussion. In order to include Daniel in group work, Ms. Wilson suggested that Iris and Jennifer propose a task that Daniel could also work on (Ms. Wilson said to Iris and Jennifer, "Give him a task to do"). In the interaction that followed (Excerpt 4), Iris used directives (utterances 3 and 7) and instructed Daniel to make a tally chart and undertake a survey of people's favourite ice cream flavour. This peripheral task was unrelated to the goal of the transforming recess unit. In utterance 9 of Excerpt 4, Iris slowed down the pace of her talk for Daniel. Because Daniel did not respond to Iris's directives or slowed-down speech, she repeated the same information four times in this short interaction that lasted for only 46 seconds. At the end of the interaction in Excerpt 4, after Iris left, Daniel went back to what he was doing before Iris came: playing with his paper, instead of continuing the task that Iris suggested.

\section{Excerpt 4}

\begin{tabular}{|c|c|c|c|}
\hline 1 & $00: 00$ & Daniel: & $\begin{array}{l}\text { If. You. Know. ((reading from a paper, while } \\
\text { looking at the paper)) }\end{array}$ \\
\hline 2 & $00: 14$ & & $\begin{array}{l}\text { ((Iris hits her desk four times and she walks } \\
\text { over to Daniel)) }\end{array}$ \\
\hline 3 & $00: 16$ & Iris: & Make a tally. What is your favourite ice cream? \\
\hline 4 & $00: 18$ & Iris: & $\begin{array}{l}\text { Favourite ice cream? ((gestures licking ice } \\
\text { cream)) }\end{array}$ \\
\hline 5 & $00: 23$ & & ((Iris sits down and looks at Daniel)) \\
\hline 6 & $00: 26$ & Iris: & Daniel, favourite ice cream? (lgestures licking \\
\hline
\end{tabular}




\begin{tabular}{|c|c|c|c|}
\hline & & & ice cream)) \\
\hline 7 & $00: 27$ & Iris: & And then give choices. \\
\hline 8 & $00: 31$ & Daniel: & Chocolate? \\
\hline 9 & $00: 34$ & Iris: & $\begin{array}{l}\text { Yeah, <chocola:te>, <vani:lla>, <stra:wberry>, } \\
\text { ((while pointing at Daniel's paper)) }\end{array}$ \\
\hline 10 & $00: 38$ & Daniel: & Chocolate? \\
\hline 11 & $00: 42$ & Iris: & $\begin{array}{l}\text { Or some other flavours. Yeah. So, favourite ice } \\
\text { cream. }\end{array}$ \\
\hline 12 & $00: 45$ & & ((Iris leaves)) \\
\hline 13 & $00: 46$ & & ((Daniel starts to play with paper)) \\
\hline
\end{tabular}

Excerpt 5 shows that the inclusion of languages other than English (as seen in utterance 2 in Excerpt 5) did not disrupt the status difference between students. In the interaction, Iris corrected Daniel's French (utterance 2). Because Daniel did not start making a tally chart in response to Iris's instructions, Iris started to write down a tally chart on Daniel's behalf. Soon after that, Daniel took the paper from Iris and started to write down the survey on his own. Looking at Daniel's engagement, Iris praised him by saying, "bien, bien, bien” in French.

\section{Excerpt 5}

\begin{tabular}{|c|c|c|c|}
\hline 1 & $00: 00$ & & ((Daniel is playing with clipboard)) \\
\hline 2 & $00: 13$ & Iris: & $\begin{array}{l}\text { Daniel? What is this? We (0.5) it's not about you. } \\
\text { You don't say "Tu." It's "la classe." La classe } \\
(0.5) \text { d'accord? }\end{array}$ \\
\hline 3 & $00: 34$ & Iris: & Vanilla. ((Iris writes on Daniel's paper)) \\
\hline 4 & & & ((Daniel plays with clipboard)) \\
\hline 5 & $00: 50$ & & ((Iris shows the paper to Daniel)) \\
\hline 6 & & & $\begin{array}{l}\text { ((Daniel looks at the paper and Iris takes it } \\
\text { away)) }\end{array}$ \\
\hline 7 & $01: 00$ & Daniel: & Wait. \\
\hline 8 & & & $\begin{array}{l}\text { ((Daniel takes the paper from Iris and starts } \\
\text { writing on it)) }\end{array}$ \\
\hline 9 & $01: 06$ & & ((Iris walks away)) \\
\hline 10 & & & ((Daniel keeps writing)) \\
\hline 11 & $01: 17$ & & ((Iris returns)) \\
\hline 12 & & & ((Daniel attaches the paper on the clipboard)) \\
\hline 13 & $01: 21$ & Iris: & Bien bien bien. \\
\hline
\end{tabular}

The interactions in Excerpts 4 and 5 together show how Iris code-switched from English to French only after Daniel did not follow her instructions and she corrected Daniel's writing in French. Iris also gave directives to Daniel, offered amplified linguistic cues for communication 
by gestures, slowed down talk, and corrected Daniel's written French, in a similar discursive structure to "foreigner talk" (Tarone, 1980, p. 423) that is often used with learners of a language. Such discursive structures simultaneously perpetuate "ratiolinguistic ideologies that conflate certain racialized bodies with linguistic deficiency" (Flores \& Rosa, 2015, p. 150). This chain of interaction positioned Iris as a more competent multilingual and Daniel as a learner of languages; in other words, this chain of interactions positioned Daniel as the Other who was deprived of speaking and expressing. As seen in Excerpts 4 and 5, even when languages other than English were used, Daniel continued to be positioned as someone being helped academically. The leader identity of Iris was thickened as she determined research questions for the survey and played a quasi teacher role. The interactions through which Iris's identity (as a leader, a teacher, and an evaluator of Daniel's work) thickened simultaneously served to marginalize Daniel and position him as someone needing academic help. The interactions involving Daniel show how geopolitical configuration of identities, in this case, local language politics shaped his positional identity and this eventually constrained him from becoming an agent of change in the transforming recess unit.

Following this interaction, Daniel started to work separately from the group on his ice cream survey, instead of pursuing the initial questions he posed about the playground that were expressed in Spanish. Daniel used a tally chart, collected data, and represented results with a bar graph; however, unlike other students who worked towards communicating their results to others, only Daniel viewed his results because his project was not connected to the goal of improving recess. Because of this lack of communicative opportunity, unlike Iris or Cathy, Daniel did not have the experience of revisiting and revising his survey and the representation of the results. At the end of the unit, Daniel's positional identity partially resulting from the permeating official monolingual policy disconnected him with the figurative identity of "agents of change."

\section{Becoming Othered: Reinforced Categorical and Binary Frameworks}

This section depicts Karim's experience: how his identity as an "English language learner" was thickened and how the Othered identity was co-constructed through the 
transforming recess unit. Unlike Daniel, whose proficiency in Spanish and French was made evident to others, there were no instances observed wherein Karim's proficiency in Farsi was made visible. In the transforming recess unit where students were grouped by their expressed interests on topics, Karim came to work with Naomi and another peer, Andrew, who showed interests in the topic of bullying at recess. Unlike Daniel's grouping, where Daniel was grouped with students who spoke his more fluent languages, Karim's grouping was not based on students' language backgrounds. Naomi was Japanese Canadian and spoke Japanese and English at home, and Andrew was Vietnamese Canadian and spoke Vietnamese and English at home. Neither of them spoke Karim's first language, Farsi, and hence unlike Daniel, Karim's translanguaging practices were masked.

During the time period in which the transforming recess unit was taking place, Karim's perceived geopolitical connection came to be associated with him during his interactions with peers. Such interactions worked against affirming his voice, as seen in the following Excerpts 6 and 7. When Karim was working with Naomi (outside the transforming recess unit, during the same academic semester), who was sitting next to him, Naomi whispered to Karim, "heard a lot about Afghanistan" (Excerpt 6, utterance 2). Naomi's utterance was out of context. Following this, during a teacher-led whole discussion, the teacher discussed fractions and made no mention of a topic related to Afghanistan. Yet, in utterance 5 in Excerpt 6, Naomi said to the teacher, "he (Karim) keeps talking to me about war" and she made an association between war and Karim. Again, the teacher's prior utterance was unrelated to war, yet Naomi introduced the topic to the class. Naomi's utterance elicited laughter from her peers as well as a directive from her teacher to stop. Karim did not respond to what Naomi or the teacher said. The series of interactions in Excerpt 6 shows how the geopolitical context brought up in relation to Karim defined him as the Other, one whose voice was deprived and silenced. During the same period of time, in another group work interaction, another student, Michael, in the class asked Karim: "Are you a son of Osama bin Ladin?" This comment provoked laughter from other students and it further Othered Karim and associated him with war and "terrorists." 


\section{Excerpt 6}

\begin{tabular}{|c|c|c|c|}
\hline 1 & $00: 00$ & & $\begin{array}{l}\text { ((Students are working individually by sitting } \\
\text { as groups of four. The teacher is walking around } \\
\text { to check students' work)) }\end{array}$ \\
\hline 2 & $00: 10$ & Naomi: & $\begin{array}{l}{ }^{\circ} \text { Heard a lot about }(0.2)>\text { Afghanistan }{ }^{\circ} \\
\text { ((Naomi whispers to Karim, while looking at him } \\
\text { and leaning toward him. Naomi goes back to the } \\
\text { original position after her utterance)) }\end{array}$ \\
\hline 3 & $00: 15$ & Karim: & $\begin{array}{l}\text { Do you have a question? ((Karim is rolling a } \\
\text { ruler)) }\end{array}$ \\
\hline 4 & & & $\begin{array}{l}\text { ((The teacher approaches to the group of Naomi. } \\
\text { Naomi starts writing on her notebook)) }\end{array}$ \\
\hline 5 & $06: 04$ & & $\begin{array}{l}\text { ((The teacher starts whole instruction. The } \\
\text { teacher is talking to the whole class in front } \\
\text { of the blackboard)) }\end{array}$ \\
\hline 6 & $07: 02$ & Ms. Wilson: & $\begin{array}{l}\text { So, we are talking one third or two thirds. We } \\
\text { are talking about what? About zero? About a } \\
\text { half? Or about a whole? Always about a half. } \\
\text { Okay? so we are trying to (0.4) you guys weren't } \\
\text { asked to do this today, we started to see } \\
\text { fractions (0.2) Karim (.) I am asking while } \\
\text { doing this exercise to start to see fractions(.) } \\
\text { are they, is it closer to zero? closer to } \\
\text { nothing? }\end{array}$ \\
\hline 7 & $07: 32$ & Naomi: & He keeps talking to me about war. \\
\hline 8 & $07: 35$ & Ms. Wilson: & Stop. [Both of you. \\
\hline 9 & $07: 35$ & Ss: & [hehehehehe \\
\hline
\end{tabular}

As van Dijk (1991) maintains, the media provides symbolic resources of racism in our daily interactions. In their meta-review, Ahmed and Matthes (2017) revealed that the media representation of Afghanistan in North America was skewed towards wars, especially towards pro-war against Muslim/Arab who were portrayed as militants and terrorists. This marginalized identity at the geopolitical level connected with Karim's positional identities. Othering of Karim happened when students were side-chatting with each other or when they were working in groups. Through peer interactions, Karim was also constituted as the Other, the target of hostility and aggression (Said, 1978).

During the transforming recess unit, groupings were based on the students' expressed interests on topics and Karim and Naomi came to work together. For group work during the transforming recess unit, Naomi proposed the question "how many times did you get bullied in 5 
months?" The teacher and students decided that Naomi would collect data from junior grade students (Grades 4 and 5) and Andrew would collect data from primary grade students (Grades 1, 2 and 3). For Karim, the teacher asked the following question: "Could you use your data? I'm wondering (.) do you think (.) when you ask your survey you can decide who you're going to ask. 'Are you an English Language Learner? Or is English your first language?" Karim nodded in response to the teacher proposal and used the tally chart (further explained below), which specifies that Karim was to collect data from "ELLs" in the school.

During the group work, Karim's contributions were frequently dismissed and minimized (as demonstrated in Excerpt 7). Excerpt 7 illustrates how Karim was positioned in the momentto-moment group work interactions. In this interaction, Karim tried to resist Naomi's question (utterance 3 "Can I help you with this?") by not verbally responding but instead working on his own. Despite Karim's resistance, she repeated her question two additional times. As marked by the change in deictic expression (from "that" to "this"), Naomi physically moved closer to what Karim was working on. Karim's suggestion to divide the task up (in utterance 5) was interrupted by Naomi (in utterance 6), when she grabbed his work, while saying "you don't know how to do this." Karim eventually leaned forward on the desk and said, "you do writing because I don't do spelling like you guys" thereby positioning himself as less competent linguistically. Not only did he have limited opportunities to speak, but he was also physically restricted from accessing the interactional space, making it difficult for him to reach the artifact that was essential to completing the survey (i.e., the tally chart for his survey).

The spatial formation of the face-to-face interaction then changed, as Karim shifted his bodily position. Specifically, Karim and Naomi were initially facing each other but toward the end of Excerpt 7, Karim put his head down on the desk and changed the direction of his eye gaze (not looking at Naomi). In this interaction, Karim positioned himself as an outsider from the inner space of interaction (Kendon, 2010). Being restricted from reaching an artifact to voice his issue of concern (in this case, the tally chart for surveys), Karim was restricted "to take up space" or "to be given an object, which allows the body to be occupied in a certain way" (Ahmed, 2007, p. 160). 


\section{Excerpt 7}

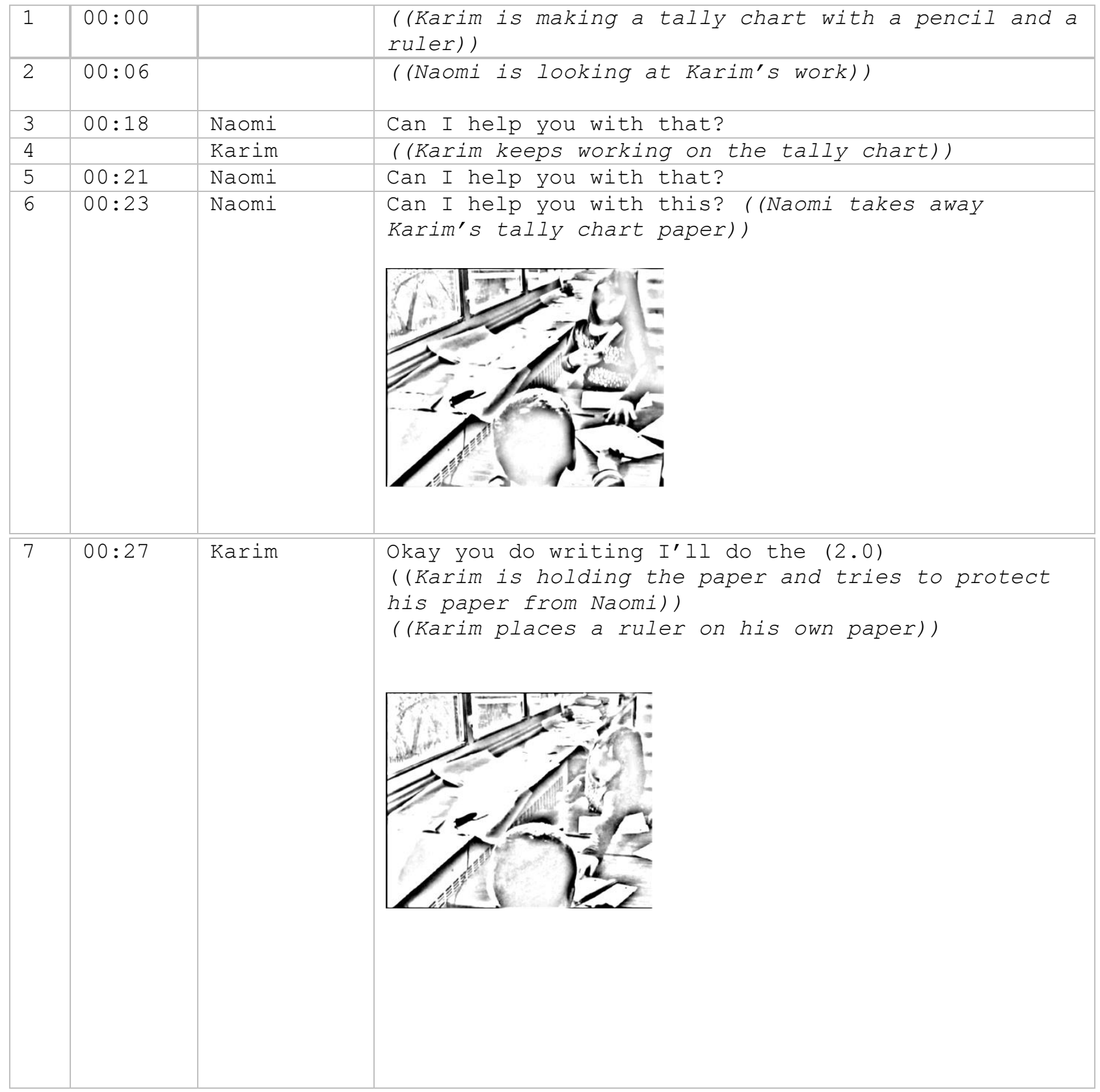

Takeuchi, M.A. (2020). Geopolitical configuration of identities and learning: Othering through the institutionalized categorization of "English language learners. Cognition and Instruction. Advance online publication https://doi.org/10.1080/07370008.2020.1825438 


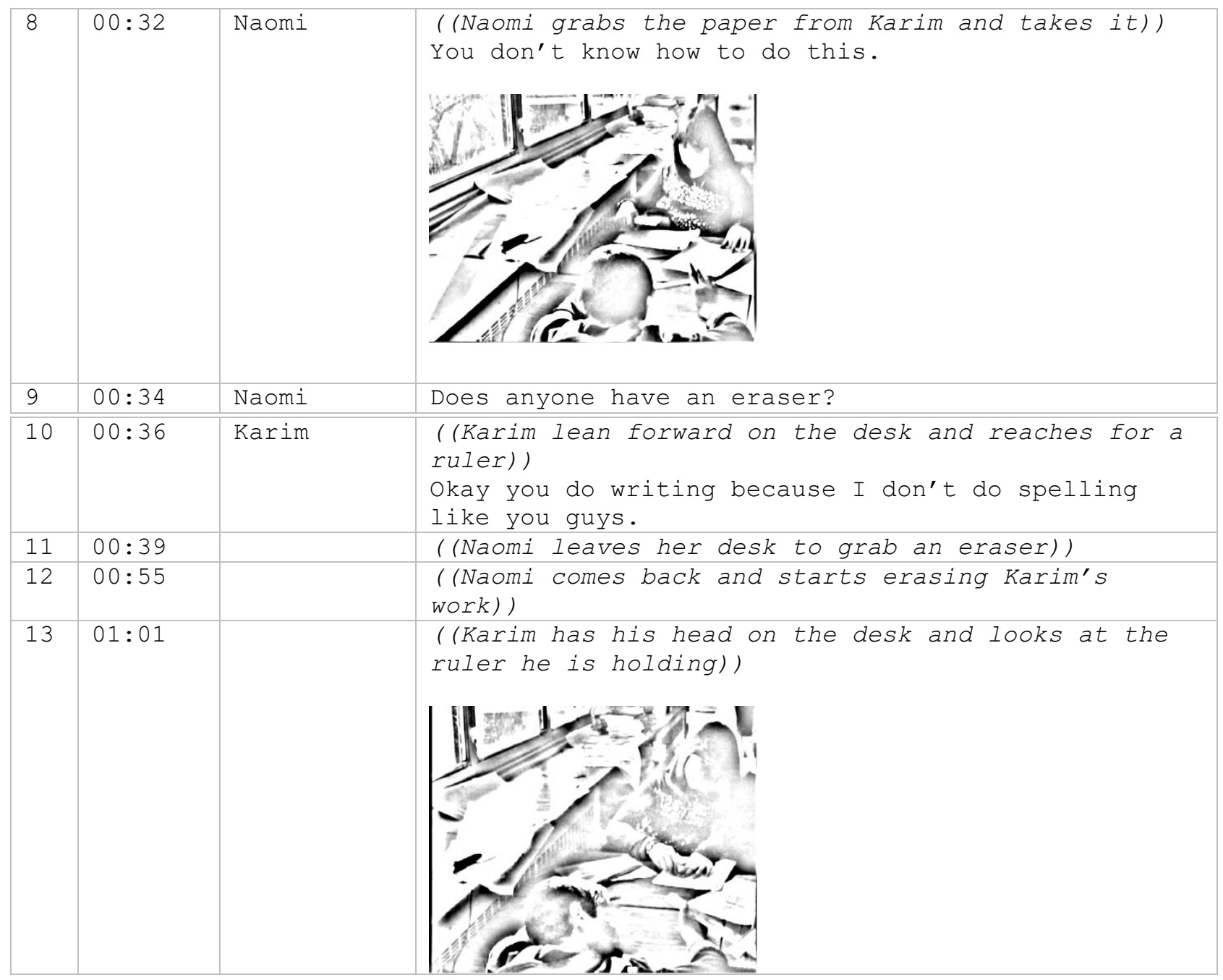

Through the type of interaction depicted in Excerpt 7, Karim came to be positioned as an outsider. Toward the end of the transforming recess unit, after noticing that Karim was not making progress, the teacher gave him more explicit instructions so that he could complete his project. At the end of this interaction, Karim summarized his survey results, as instructed by the teacher in Excerpt 8. 


\section{Excerpt 8}

\begin{tabular}{|c|c|c|c|}
\hline 1 & $00: 00$ & & (( Karim leaves the table and walks away)) \\
\hline 2 & $00: 04$ & Ms. Wilson: & $\begin{array}{l}\text { Karim? Karim? Come here. } \\
\text { ((Teacher pulls out a chair at the group)) }\end{array}$ \\
\hline 3 & $00: 13$ & Ms. Wilson & $\begin{array}{l}\text { ((Teacher is showing a table she created on a } \\
\text { blackboard; variables are set up as "Boys" } \\
\text { "Girls" and "ELLs" based on Karim's survey)) } \\
\text { This is going to be English Language Learners } \\
\text { and their results. You asked who? (0.4) Boys? } \\
\text { Or girls? }\end{array}$ \\
\hline 4 & $00: 19$ & Karim: & Boys. \\
\hline 5 & $00: 23$ & Ms. Wilson: & $\begin{array}{l}\text { ((The teacher fills the information on the } \\
\text { table she created)) }\end{array}$ \\
\hline 6 & $00: 28$ & Ms. Wilson: & $\begin{array}{l}\text { So, everybody in your group is making this } \\
\text { table. You've got your choices and you'll } \\
\text { write them here. For choice one, which was } \\
\text { everyday (0.2) how many people who are English } \\
\text { Language Learners chose it? How many people } \\
\text { for boys and how many people for girls? }\end{array}$ \\
\hline 7 & $00: 52$ & Ms. Wilson: & $\begin{array}{l}\text { All of you are going to have this table. So } \\
\text { copy it now onto your ( } 3.0) \text { ((Teacher moves } \\
\text { close to Karim and points at his paper)) } \\
\text { you're going to take (0.1) first set it up. } \\
\text { Before you put the data in, set up your table. } \\
\text { And then I'm going to come back. }\end{array}$ \\
\hline 8 & $01: 07$ & Karim: & I think our choices are $=$ \\
\hline 9 & $01: 09$ & Ms. Wilson: & $\begin{array}{l}\text { No. Set it up exactly like this. ((Teacher } \\
\text { points at the table on a blackboard)) Okay? } \\
\text { And you're going to write your choices in } \\
\text { here. }\end{array}$ \\
\hline
\end{tabular}

As seen in Figure 6, using a bar graph, Karim's survey compared the frequency of being bullied among boys, girls, and ELLs. In the process of creating a table and graph, Karim reproduced categories of "ELLs," "boys," and "girls." The final graph Karim completed directed the viewer's attention to the most frequent number, which was 46 boys who answered "none" for Karim's question: “How many times did you get bullied in 5 months?” In fact, reflecting on this graph, Karim wrote: "I found out that boys most don't get bullied and it is 46." He did not refer to other students' experiences. In this sense, this mathematical representation perpetuated the norm that existed in the school or at a larger society: Karim himself came to reinforce the label of English language learners and also taken-for-granted categories of boys and girls. As well, he focused on the most frequent number in the survey - those who did not experience bullying, 
rather than the voices of those who were bullied. His attention to the most frequent number in the graph, together with the positional identities and geopolitical configuration of the Other imposed on him, prevented Karim from accessing the figurative identity of "agents of change."

\section{Figure 6}

Karim's Survey

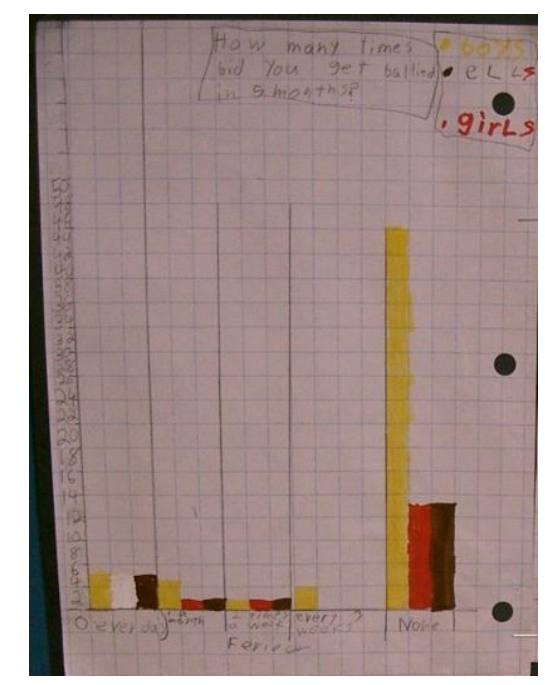

\section{Discussion}

This article focused on a mathematics unit (entitled "the transforming recess unit") designed to honour young students' voices and experiences in the playground and demonstrated the value of attending to multi-layered identities that are inextricably tied with learner experiences. The analysis highlighted how students' access to the agentive figurative identity ("agents of change") was influenced by moment-by-moment positional identities but also by thickened geopolitical configuration and colonial matrix of identities. Methodologically, this article depicted both visible and less visible pictures of identities and learner experiences that are embedded in macro-level geopolitical contexts. The stories of Iris and Cathy exemplified cases in which students were able to use surveys as a tool to voice their ideas and become agents of 
change. Iris and Cathy took the opportunity to convince school authorities to change the current school policies for recess and the playground distribution system to foster friendship. Their leader identity was further laminated through moment-by-moment interactions and also as they enacted the figurative identity of "agents of change" through the transforming recess unit.

However, under this seemingly ideal pedagogical design and even with the teacher's efforts to include all students to become "agents of change," interactions in the classroom were still nested in macro-level geopolitical contexts. The geopolitical configuration of identities influenced learners' access to becoming "agents of change" through micro-level interactions as seen in the cases of Daniel and Karim who were labeled as "English language learners," an institutionalized label that inscribes colonial history and emphasizes their deficits and their needs to be helped. In the forefront of this article was the geopolitical configurations of identities, operating through macro-level contexts including language policies (of the hegemony of English) and media portrayal in the West (of war and terrorists). Such geopolitical configuration of identities interacted with the positional identities at a micro-scale and eventually restricted learners' access to figurative identities as agents of change.

\section{Centralizing Power and the Geopolitical Configuration of Identities in Learning}

This article underlines the value of attending to the layer of the geopolitical configuration of identities including co-construction of the Other (Said, 1978). In the case of Karim who was categorized as an "English language learner," media portrayals of terrorism became symbolic resources of interaction (van Dijk, 1991) and restricted Karim's movement and access, as he came to be associated with war and terrorists (Ahmed, 2007). This Othered identity influenced the way he was subsequently positioned by others and the way he positioned himself, as well as his access to the figurative identity of "agents of change." Entangled with the inherited history (Ahmed, 2007), Karim was deprived of access to key artifacts, opportunities to speak up, and eventually, he himself contributed to thickening the ELL identity by saying "I don't do spelling like you guys," by repositioning his body to distance himself from others, or by using the category of ELLs in his survey. The initial interactions we observed involving Daniel gave a glimmer of hope that he would be positioned as a multilingual; however, due to the pervading 
local monolingual policy, the multilingual identity was overpowered. Instead, the ELL identity came to be thickened even when languages other than English were used among peers. These interactions happened even while the teacher and peers attempted to create a context of inclusion wherein Daniel could be positioned as a multilingual and where Karim could use social resources (e.g., doing surveys with fellow "ELLs").

Geopolitical configuration of identities was largely shaped outside the school but presented itself significantly and was reinforced in the school context. Foucault (1980) maintains that power "reaches into the very grain of individuals, touches their bodies and inserts itself into their actions and attitudes, their discourses, learning processes and everyday lives" (p. 39). Power is the central issue in the slices of everyday interactions shown in this article; the actions and discourse from the teacher and students were inherently entangled with power. On identity, Foucault (1983) states that "the target nowadays is not to discover what we are but to refuse what we are" (p. 216). What Foucault cautions here is how the power to mask individuality and impose an identity recognizable by others penetrates into our daily interactions and everyday practices.

By centralizing the layer of the geopolitical configuration of the Other and the discussion on power, the analysis and findings presented in this article further amplify the current scholarship on identities, power, and mathematics learning (e.g., Esmonde et al., 2009; McGee \& Martin, 2011; Nasir, 2004; Nasir \& de Royston, 2013; Leyva, 2016). The current body of scholarship on "English language learners" and mathematics education tends to focus on Spanish-English (emergent) bilinguals in the United States (de Araujo et al., 2018). The idiosyncratic context of this study — a "linguistically diverse" English monolingual school, with transnational participants, in an officially bilingual country - allowed me to gauge the geopolitical matrix in identities and learning, where the politics between the West and the Orient (Said, 1978) manifested through local language politics and students' take-up of media portrayals.

Consistent with the theoretical discussion critiquing the use of the deficit-oriented label of "English language learners" (Civil, 2014; Flores \& Rosa, 2015; García \& Leiva, 2014; Gutiérrez \& Orellana, 2006), this study offers empirical accounts of how such a label served "as 
a context that acquires children" (McDermott, 1993, p. 275). Similar to Adam depicted in McDermott (1993), Daniel and Karim were actively attempting to resist the way others tried to impose certain identities on them; however, in this very process, they were entangled with being the Other and their participation was limited to what the institutional label of ELLs afforded them. In the micro-interactions of active circumventing of labels imposed on them, they came to be entangled with the very power that marginalized them. For example, Daniel's relegated participation in the ice cream flavour survey (assigned from a leader, multilingual student) further deviated him from critical mathematical literacy "to critique institutional structures with the goal of transforming them" (Gustein, 2006, p. 210-211).

Replacing a deficit-oriented label with a more asset-oriented label (e.g., emergent bilinguals) is certainly progress (García \& Leiva, 2014). However, unless the underlying monolingual policies and practices are questioned and challenged (Cummins, 2007; García \& Leiva, 2014; Michener et al., 2015), simply replacing the label will likely not change the dynamics of identities and learning. This is because, as the findings of this study suggest, the macro-level geopolitical configuration of the Other (even without the presence of the label of "ELLs") can continue to serve as a context to reinforce such a label.

In lieu of replacing labels, can we imagine praxis for subverting categorical and binary frameworks that continue to shape institutionalized practices of schooling and learning? Such institutionalized practices extend beyond categorization of "English language learners" and include perpetuation of cultural learning styles problematized by Gutiérrez and Rogoff (2003) and genderism desrupted by Esmonde (2011). As Takeuchi et al. (2020) pointed out, categorical and binary frameworks can also shape and limit the institutionalized practice of research: "the risk of reducing our intersectional histories and experiences to deterministic categories is the further subjugation of learners and erasure of the heterogeneity of their histories, desires and experiences by disciplinary apparatus" (p. 25). Rigid institutionalized practices can orient us toward "dehumanization, which marks not only those whose humanity has been stolen, but also those who have stolen (...) distortion of the vocation of becoming more fully human" (Freire, 1970, p. 28). In the unit depicted in this study, which was shaped by mathematics curriculum, Karim conducted a survey about bullying experiences that ultimately reinforced categorical and 
binary frameworks that inscribed gender binaries and separated ELLs from others. Within this categorical and binary framework, he focused on the majority- "boys who never experienced bullying." This finding calls for transforming taken-for-granted labelling and related institutionalized practices through which representation of the Other has been co-constructed. In other words, such intervention can queer taken-for-granted labels and variables, meaning that we take a conscientious distance from the normative categories (Kumashiro, 2002; McWilliams, 2016). Queering through classroom practices could mean questioning the perpetuation of normative variables and categories in mathematics learning and beyond. Alternatively, as seen in Spivak's (1985) argument on the strategic use of positivistic essentialism led by historically silenced groups toward societal changes, it could also mean embracing learner-led (re)labelling and (re)generation of relevant variables to voice their silenced perspectives.

In this light, the findings of this study fundamentally call for the design of learning environments that allow teachers and learners the space to critically examine ideologies (Philip et al., 2018), macroethics (Gupta et al., 2019) and racism (Hostetler et al., 2018; McGee \& Martin, 2011; Philip et al., 2016), toward the hope "to rehumanize the Other" (Langer-Osuna \& Nasir, 2016, p. 726). As Hostetler et al. (2018) argue, such learning environments should be deliberately designed to surface silenced voices and experiences. This in turn necessitates reorienting (Ahmed, 2006) disciplinary forms by creating opportunities for learners to progressively recontextualize disciplinary practices and tools in ways that acknowledge and support discursive enactments of the uncertainties and fears that they inhabit (Sengupta et al., in press). Previous literature on teaching mathematics for social justice similarly demonstrates the possibility of repositioning mathematics as critical mathematics literacy to disrupt the status quo (e.g., Das \& Adams, 2019; Enyedy \& Mukhopadhyay, 2007; Philip et al., 2016; Rubel et al., 2016; Turner et al., 2009). Designing a curriculum and learning environment to embrace such critical mathematical literacy and to interrogate the media portrayal in the West could be a potentially promising way to rehumanize learners whose experiences, movement, and access are constrained through the colonial historicity we inherit (Ahmed, 2007).

In the scope of this article, focusing on the transforming recess unit, illuminated was the interactions in which Karim and Daniel were Othered; however, over the course of one academic 
year, there were contexts wherein these students were recognized for what they could do and show mathematically, without their Othered identity being thickened. The key, in these contexts, was the mutually-developing friendships that were characterized by interactions wherein the learners were not defined by labels assigned to them (Takeuchi, 2016). It was also crucial to design a learning environment, wherein learners' subjugated and hidden embodied knowledge came to be part of their language (Takeuchi \& Dadkhahfard, 2019). Ironically, in the pedagogical design of the transforming recess unit, where embracing students' voices and encouraging students to become agents of change were the central design principles, neither friendship nor disruption of linguistic hegemony were centralized. In other words, the questions around the "For Whom" and "With Whom" in learning were not well attended in the context of pedagogical design (Philip, Bang, \& Jackson, 2018). This finding suggests that the design of learning environments should leverage disruption of epistemic, linguistic, and disciplinary hegemony and development of decolonial relationships to the core of its design. As Paré et al. (2019) demonstrated, the space of friendships and care can queer the seemingly rigid categories and representations. Such design will have the capacity to strengthen and amplify the growing body of research on power, identities, design, and learning in the field of the learning sciences (Bang \& Vossoughi, 2016; Esmonde \& Booker, 2016; Hand et al., 2012; Philip et al., 2018; Vakil et al., 2016).

\section{Toward Future Studies}

In order to envisage future studies based on the findings from this study, I propose the following three areas: 1) re-designing learning environments that challenge the hegemony of English, 2) understanding the enduring influence of the experiences of micro-level marginalization on development across multiple time scales, and 3) disrupting Othered identities configured through the geopolitical and colonial matrix. The analysis of the transforming recess unit suggested that students' substantive contributions were mostly recognized through speaking and writing. Although representations such as a double bar graph were used, to make themselves recognizable as agents of change, students still needed to summarize their motivation in the project, main findings, and proposals for action in oral and written English. As the results 
showed, this privilege on one mode of communication over others created the situation wherein Karim gave up on his contributions by acknowledging his limited English language proficiency. Ironically, the innovative pedagogy that aimed to invite students' voices served to (inadvertently) marginalize the voices that were not expressed in oral and written English and hence reproduced the hegemony of English (Canagarajah, 1999). This is in contrast with findings obtained in the contexts wherein (emergent) bilingual learners exhibited their mathematical contributions through various modes of communication (including embodied multimodal expressions and nonEnglish languages; Dominguez et al., 2014; Fernandes et al., 2017; Takeuchi, 2018; Takeuchi \& Dadkhahfard, 2019; Turner et al., 2013; Zahner \& Moschkovich, 2011). Findings from this study call for the re-design of learning environments that challenges the hegemony of English, wherein learners' voices are recognized in multimodal ways to be agents of change who can transform the institutionalized practices.

What is the enduring influence of the experiences of micro-level marginalization on longitudinal development — both on a person's development across a life span and on macrolevel societal development? How can learning help subvert marginalization at different time scales? These pressing questions are provoked by the intersection between the history of society and learner identity development across a life span that Scribner (1985) maintained and also by the lived experiences of learners depicted in this article. The current dataset is limited in timespan as students' experiences within the transforming recess unit endured half of the academic year and my involvement with the school and students was limited to two consecutive years. However, these pressing questions warrant future studies. Longitudinal commitment to learners and their learning environments over years can show us otherwise-impossible ontological and epistemological transformations (as seen in works by Cole \& Packer, 2016; Lehrer \& Schauble, 2000). Learner experiences, especially over longer periods of time (e.g., months or years as opposed to short-term "intervention" studies that typically unfold over hours or days) are inherently heterogeneous and should be seen as such by researchers, as it is in such experiences that illuminate how learners remake disciplinary histories through multivocality (Sengupta et al., in press). Attention to different scales of history can shine light on such heterogenous experiences in the space of learning, including how learners come to reverse social 
hierarchy and build caring relationships with each other through subtle everyday acts (Vossoughi et al., 2020).

The findings of this article call for more learning sciences research that investigates dehumanization resulting from the macro-level geopolitical configuration and colonial matrix of identities. Envisioning the design of an equitable learning environment, Nasir (2004) called for understanding a context where "the resistant behaviors of minority children play out in schools (...) do not become a determinant of identity or schooling outcomes" (p. 154). The resistant behaviours by a Muslim African American student in Nasir's (2004) study were not deterministic to his identity in the school context as a result of the presence of what Nasir called "ideational artifacts" (p. 179) that engraved humanized ways of seeing children and their families. The design of all learning environments should centralize the creation of a space where Othered identities are rehumanized (Langer-Osuna \& Nasir, 2016), especially in this era of rising hostilities and nationalism (The Politics of Learning Writing Collective, 2017). Disrupting Othered identities configured through the geopolitical and colonial matrix will change the landscape of who is afforded and who is restricted from opportunities to develop "a sense of one's own identity in the broad context of time" (Gutiérrez \& Jurow, 2016, p. 567) toward the generation of newly-imagined practices. Embracing historically silenced voices can create a more humane history anew.

\section{Acknowledgements:}

I would like to express my appreciation to the teacher and students who were willing to have me in their classroom and collaborate with this study. I would like to thank Dr. Indigo Esmonde, Dr. Lesley Dookie, Dr. Judit Moschkovich, Dr. Thomas Philip, and Dr. Pratim Sengupta for their support and constructive feedback on earlier versions of this manuscript. I also appreciate expertise of Dr. Beverly Caswell, Dr. Nicole West-Burns, and Jeff Kugler who helped to shape the professional development seminar that was described in this article. I appreciate Shima Dadkhahfard for her help with the image that appeared in this manuscript. My appreciation also goes to the editors and anonymous reviewers of Cognition and Instruction, who all provided detailed and constructive feedback. 


\section{References}

Ahmed, S. (2006). Queer phenomenology: Orientations, objects, others. Duke University Press.

Ahmed, S. (2007). A phenomenology of whiteness. Feminist Theory, 8(2), 149-168. https://doi.org/10.1177/1464700107078139

Ahmed, S., \& Matthes, J. (2017). Media representation of Muslims and Islam from 2000 to 2015: A meta-analysis. International Communication Gazette, 79(3), 219-244. https://doi.org/10.1177/1748048516656305

Anyon, J. (1981). Social class and school knowledge. Curriculum Inquiry, 11(1), 3-42. https://doi.org/10.1080/03626784.1981.11075236

Bang, M., \& Vossoughi, S. (2016). Participatory design research and educational justice:

Studying learning and relations within social change making. Cognition and Instruction, 34(3), 173-193. https://doi.org/10.1080/07370008.2016.1181879

Bishop, J. (2012). She's always been the smart one. I've always been the dumb one: Identities in the mathematics classroom. Journal for Research in Mathematics Education, 43(1), 34-74. https://doi.org/10.5951/jresematheduc.43.1.0034

Cammarota, J., \& Fine, M. (2008). Revolutionizing education: Youth Participatory Action Research in motion. Routledge.

Canagarajah, A. S. (1999). Resisting linguistic imperialism in English teaching. Oxford University Press.

Civil, M. (2014). Musings around participation in hte mathematics classroom. The Mathematics Educator, 23(2), 3-22. Retrieved from https://openjournals.libs.uga.edu/tme/index

Civil, M., \& Turner, E. E. (2015). The common core state standards in mathematics for English language learners. TESOL Press \& NCTM.

Cole, M., \& Packer, M. (2016). Design-based intervention research as the science of the doubly artificial. Journal of the Learning Sciences, 25(4), 503-530. https://doi.org/10.1080/10508406.2016.1187148

Cummins, J. (2004). Technology, literacy, and young second language learners: Designing educational futures. Paper presented at the Technology in Support of Young Second Language Learners Project, CA.

Cummins, J. (2007). Rethinking monolingual instructional strategies in multilingual classrooms. Canadian Journal of Applied Linguistics, 10(2), 221-241. Retrieved from https://journals.lib.unb.ca/index.php/CJAL

Das, A., \& Adams, J. (2019). Critical transdisciplinary STEM: A critical numeracy approach to STEM praxis by Urban environments and education research coven. In P. Sengupta., M.C. Shanahan., \& B. Kim (Eds.). Critical, transdisciplinary and embodied approaches in STEM education (pp. 291-306). New York, NY: Springer. 
de Araujo, Z., Roberts, S. A., Willey, C., \& Zahner, W. (2018). English learners in K-12 mathematics education: A review of the literature. Review of Educational Research, 88(6), 879-919. https://doi.org/10.3102/0034654318798093

de Araujo, Z., Smith, E., \& Sakow, M. (2016). Reflecting on the dialogue regarding the mathematics education of English Learners. Journal of Urban Mathematics Education, 9(2), 33-48. Retrieved from https://journals.tdl.org/jume/index.php/JUME

Derry, S., Pea, R., Barron, B., Engle, R., Erickson, F., Goldman, R., ... Sherin, B. (2010).

Conducting video research in the learning sciences: Guidance on selection, analysis, technology, and ethics. Journal of the Learning Sciences, 19(1), 3-53. https://doi.org/10.1080/10508400903452884

Delpit, L. D. (1988). The silenced dialogue: Pedagogy and power in educating other people's children. Harvard Educational Review, 58, 280-298. https://doi.org/10.17763/haer.58.3.c43481778r528qw4

Dominguez, H., LópezLeiva, C. A., \& Khisty, L. L. (2014). Relational engagement: Proportional reasoning with bilingual Latino/a students. Educational Studies in Mathematics, 85(1), 143160. https://doi.org/10.1007/s10649-013-9501-7

Emerson, R., Fretz, R., \& Shaw, L. (2011). In the field: Participating, observing and jotting notes. In Writing ethnographic fieldnotes (2nd Ed, pp. 21-41). The University of Chicago Press.

Enyedy, N., \& Mukhopadhyay, S. (2007). They don't show nothing I didn't know: Emergent tensions between culturally relevant pedagogy and mathematics pedagogy. Journal of the Learning Sciences, 16(2), 139-174. https://doi.org/10.1080/10508400701193671

Erickson, F. (1984). What makes school ethnography ethnographic? Anthropology \& Education Quarterly, 15(1), 51-66. https://doi.org/10.1525/aeq.1984.15.1.05x1472p

Esmonde, I., \& Booker, A. N. (2016). Power and privilege in the learning sciences: Critical and sociocultural theories of learning. Taylor \& Francis.

Esmonde, I. (2011). Snips and snails and puppy dogs' tails: Genderism and mathematics education. For the Learning of Mathematics, 31(2), 27-31.

Esmonde, I., Brodie, K., Dookie, L., \& Takeuchi, M. (2009). Social identities and opportunities to learn: Student perspectives on group work in an urban mathematics classroom. Journal of Urban Mathematics Education, 2 (2), 18-45. Retrieved from https://journals.tdl.org/jume/index.php/JUME

Fernandes, A., Kahn, L. H., \& Civil, M. (2017). A closer look at bilingual students' use of multimodality in the context of an area comparison problem from a large-scale assessment. Educational Studies in Mathematics, 95(3), 263-282. https://doi.org/10.1007/s10649-0179748-5

Fine, M., \& Torre, M. E. (2004). Re-membering exclusions: Participatory action research in public institutions. Qualitative Research in Psychology, 1(1), 15-37. 
https://doi.org/10.1191/1478088704qp003oa

Flores, N., \& Rosa, J. (2015). Undoing appropriateness: Raciolinguistic ideologies and language diversity in education. Harvard Educational Review, 85(2), 149-171.

https://doi.org/10.17763/0017-8055.85.2.149

Foucault, M. (1980). Power/knowledge: Selected interviews and other writings 1972-1977. Vintage Books.

Foucault, M. (1983). The subject and power. In H. Dreyfus and P. Rabinow (Eds.). Michel Foucault, beyond structuralism and hermeneutics (pp. 208-229). The University of Chicago Press.

Freire, P. (1970). Pedagogy of the oppressed. Continuum.

García, O., \& Leiva, C. (2014). Theorizing and enacting translanguaging for social justice. In A. Blackledeg \& A. Creese (Eds.), Heteroglossia as practice and pedagogy (pp. 119-216). Springer.

Geertz, C. (1973). Thick description: Toward an interpretive theory of culture. In The interpretation of cultures (pp. 3-30). Basic Books.

Goffman, E. (1974). Frame analysis: An essay on the organization of experience. Harvard University Press.

Gholson, M., \& Martin, D. B. (2014). Smart girls, Black girls, mean girls, and bullies: At the intersection of identities and the mediating role of young girls' social network in mathematical communities of practice. Journal of Education, 194(1), 19-33.

Goodwin, M. H., \& Cekaite, A. (2013). Calibration in directive/response sequences in family interaction. Journal of Pragmatics, 46(1), 122-138.

Graven, M., \& Heyd-Metzuyanim, E. (2019). Mathematics identity research: the state of the art and future directions. ZDM: Mathematics Education, 51(3), 361-377.

Gupta, A., Turpen, C., Philip, T., \& Elby, A. (2019). Narrative co-construction of stances towards engineers' work in socio-technical contexts. In P. Sengupta., M.-C. Shanahan., \& B. Kim (Eds.). Critical, transdisciplinary and embodied approaches in STEM education (pp. 251-272). Springer.

Gustein, E. (2006). Reading and writing the world with mathematics: Toward a pedagogy for social justice. Routledge.

Gutiérrez, K. D. (2016). Designing resilient ecologies: Social design experiments and a new social imagination. Educational Researcher, 45(3), 187-196. https://doi.org/10.3102/0013189X16645430

Gutiérrez, K. D., \& Jurow, A. S. (2016). Social design experiments: Toward equity by design. Journal of the Learning Sciences, 25(4), 565-598. https://doi.org/10.1080/10508406.2016.1204548

Gutiérrez, K. D., \& Orellana, M. (2006). The "problem” of English learners: Constructing genres of difference. Research in the Teaching of English, 40(4), 502-507. 
https://doi.org/10.2307/40171712

Gutiérrez, K. D., \& Rogoff, B. (2003). Cultural ways of learning: Individual traits or repertoires of practice. Educational Researcher, 32(5), 19-25.

https://doi.org/10.3102/0013189X032005019

Hand, V., \& Gresalfi, M. (2015). The joint accomplishment of identity. Educational Psychologist, 50(3), 190-203. https://doi.org/10.1080/00461520.2015.1075401

Hand, V., Penuel, W. R., \& Gutiérrez, K. D. (2012). (Re)framing educational possibility: Attending to power and equity in shaping access to and within learning opportunities. Human Development, 55(5-6), 250-268. https://doi.org/10.1159/000345313

Hanks, W. F. (2009). Fieldwork on deixis. Journal of Pragmatics, 41(1), 10-24. https://doi.org/10.1016/j.pragma.2008.09.003

Hepburn, A., \& Bolden, G. B. (2013). The conversation analytic approach to transcription. In J.Sidnell \& T. Stivers (Eds.). The handbook of conversation analysis (pp. 57-76). Blackwell.

Holland, D., \& Leander, K. (2004). Ethnographic studies of positioning and subjectivity: an introduction. Ethos, 32(2), 127-139. https://doi.org/10.1525/eth.2004.32.2.127

Holland, D., Skinner, D., Lachicotte Jr, W., \& Cain, C. (1998). Identity and agency in cultural worlds. Harvard University Press .

Hostetler, A., Sengupta, P., \& Hollett, T. (2018). Unsilencing critical conversations in socialstudies teacher education using agent-based modeling. Cognition and Instruction, 36(2), 139-170. https://doi.org/10.1080/07370008.2017.1420653

Jordan, B., \& Henderson, A. (1995). Interactional analysis: Foundations and practice. The Journal of the Learning Sciences, 4(1), 39-103. https://doi.org/10.1207/s15327809j1s0401_2

Kendon, A. (2010). Spacing and orientation in co-present interaction. In A. Esposito, N. Campbell, C. Vogel, A. Hussain, \& A. Nijholt (Eds.), Development of multimodal interfaces: Active listening and synchrony. (pp. 1-15). Springer.

Kersaint, G., Thompson, D. R., \& Petkova, M. (2008). Teaching mathematics to English language learners. Routledge.

Kumashiro, K. (2002). Troubling education:" Queer" activism and anti-Oppressive pedagogy. Routledge.

Langer-Osuna, J. M. (2016). The social construction of authority among peers and its implications for collaborative mathematics problem solving. Mathematical Thinking and Learning, 18(2), 107-124. https://doi.org/10.1080/10986065.2016.1148529

Langer-Osuna, J. M., \& Nasir, N. S. (2016). Rehumanizing the "other" race, culture, and identity in education research. Review of Research in Education, 40(1), 723-743. https://doi.org/10.3102/0091732X16676468

Lave, J., \& Wenger, E. (1991). Situated learning: Legitimate peripheral participation. 


\section{Cambridge University Press.}

Lehrer, R., \& Schauble, L. (2000). Developing model-based reasoning in mathematics and science. Journal of Applied Developmental Psychology, 21(1), 39-48. https://doi.org/10.1016/S0193-3973(99)00049-0

Leyva, L. A. (2016). An intersectional analysis of Latin@ college women's counter-stories in mathematics. Journal of Urban Mathematics Education, 9(2), 81-121. Retrieved from https://journals.tdl.org/jume/index.php/JUME

McDermott, R. P. (1993). The acquisition of a child by a learning disability. In S. Chaiklin \& J. Lave (Eds.), Understanding practice: Perspectives on activity and context. (pp. 269-305). Cambridge University Press.

McGee, E. O., \& Martin, D. B. (2011). "You would not believe what i have to go through to prove my intellectual value!" Stereotype management among academically successful black mathematics and engineering students. American Educational Research Journal, 48(6), 1347-1389. https://doi.org/10.3102/0002831211423972

McWilliams, J. (2016). Queering participatory design research. Cognition and Instruction, 34(3), 259-274. https://doi.org/10.1080/07370008.2016.1172436

Michener, C. J., Sengupta-Irving, T., Proctor, C. P. ., \& Silverman, R. (2015). Culturally sustaining pedagogy within monolingual language policy: variability in instruction. Language Policy, 14(3), 199-220. https://doi.org/10.1007/s10993-013-9314-7

Mignolo, W. D. (2009). Epistemic disobedience, independent thought and decolonial freedom. Theory, Culture \& Society, 26(8), 159-181. https://doi.org/10.1177/0263276409349275

Moschkovich, J. (2007). Bilingual mathematics learners: How views of language, bilingual learners, and mathematical communication impact instruction. In N. S. Nasir \& P. Cobb (Eds.), Improving access to mathematics: Diversity and equity in the classroom (pp. 89104). Teachers College Press.

Nasir, N. S. (2004). "Halal-ing" the chiild: Reframing identities of resistance in an urban muslim school. Harvard Educational Review, 74(2), 153-174. https://doi.org/10.17763/haer.74.2.x203671222708725

Nasir, N. S., \& de Royston, M. M. (2013). Power, identity, and mathematical practices outside and inside school. Journal for Research in Mathematics Education, 44(1), 264-287. https://doi.org/10.5951/jresematheduc.44.1.0264

Paré, D., Sengupta, P., Windsor, S., Craig, J., \& Thompson, M. (2019). Queering virtual reality: A prolegomenon. In P. Sengupta., M.-C. Shanahan., \& B. Kim (Eds.). Critical, transdisciplinary and embodied approaches in STEM education (pp. 307-328). New York, NY: Springer.

Philip, T. M., \& Gupta, A. (2020). Emerging perspectives on the co-construction of power and learning in the learning sciences, mathematics education, and science education. Review of Research in Education, 44(1), 195-217. https://doi.org/10.3102/0091732X20903309 
Philip, T. M., Bang, M., \& Jackson, K. (2018). Articulating the "How," the "For What," the "For Whom," and the "With Whom" in concert: A call to broaden the benchmarks of our scholarship. Cognition and Instruction, 36(2), 83-88.

https://doi.org/10.1080/07370008.2018.1413530

Philip, T. M., Gupta, A., Elby, A., \& Turpen, C. (2018). Why ideology matters for learning : A case of ideological convergence in an engineering ethics classroom discussion on drone warfare. Journal of the Learning Sciences, 27(2), 183-223.

https://doi.org/10.1080/10508406.2017.1381964

Philip, T. M., Olivares-Pasillas, M. C., \& Rocha, J. (2016). Becoming racially literate about data and data-literate about race: Data visualizations in the classroom as a site of racialideological micro-contestations. Cognition and Instruction, 34(4), 361-388. https://doi.org/10.1080/07370008.2016.1210418

Planas, N., \& Civil, M. (2013). Language-as-resource and language-as-political: Tensions in the bilingual mathematics classroom. Mathematics Education Research Journal, 25(3), 361378. https://doi.org/10.1007/s13394-013-0075-6

The Politics of Learning Writing Collective. (2017). The Learning Sciences in a new era of U.S. nationalism. Cognition and Instruction, 35(2), 91-102. https://doi.org/10.1080/07370008.2017.1282486

Radovic, D., Black, L., Williams, J., \& Salas, C. E. (2018). Towards conceptual coherence in the research on mathematics learner identity: A systematic review of the literature. Educational Studies in Mathematics, 99, 21-42. https://doi.org/10.1007/s10649-018-9819-2

Rubel, L. H., Lim, V. Y., Hall-Wieckert, M., \& Sullivan, M. (2016). Teaching mathematics for spatial justice: An investigation of the lottery. Cognition and Instruction, 34(1), 1-26. https://doi.org/10.1080/07370008.2015.1118691

Said, E. W. (1978). Orientalism. Pantheon Books.

Scribner, S. (1985). Vygotsky's uses of history. In J. V Wertsch (Ed.), Culture, communication, and cognition: Vygotskian perspectives (pp. 119-145). Cambridge University Press.

Sengupta, P., Dickes, A., \& Farris, A. (in press). Voicing code in STEM: A dialogical imagination. The MIT Press.

Spivak, G. (1985). Subaltern studies: Deconstructing historiography. In J. Culler (Ed.), Deconstruction: Critical concepts in literary and cultural studies (pp. 220-244). Routledge.

Tarone, E. (1980). Communication strategies, foreigner talk, and repair in interlanguage. Language learning, 30(2), 417-428. https://doi.org/10.1111/j.1467-1770.1980.tb00326.x

Takeuchi, M.A., Sengupta, P., Shanahan, M-C., Adams, J.D., \& Hachem, M. (2020).

Transdisciplinarity in STEM education: A critical review. Studies in Science Education, 56 (2), 213-253. https://doi.org/10.1080/03057267.2020.1755802

Takeuchi, M.A. \& Dadkhahfard, S. (2019). Rethinking bodies of learners through STEM education. In P. Sengupta., M-C. Shanahan., \& B. Kim (Eds.). Critical, transdisciplinary 
and embodied approaches in STEM education (pp. 199-216). New York, NY: Springer.

Takeuchi, M. A. (2018). Power and identity in immigrant parents' involvement in early years mathematics learning. Educational Studies in Mathematics, 97 (1), 39-53. https://doi.org/10.1007/s10649-017-9781-4

Takeuchi, M. A. (2016). Friendships and group work in linguistically diverse mathematics classrooms: Opportunities to learn for English language learners. Journal of the Learning Sciences, 25 (3), 411-437. https://doi.org/10.1080/10508406.2016.1169422

Turner, E., Dominguez, H., Maldonado, L., \& Empson, S. (2013). English learners' participation in mathematical discussion: Shifting positionings and dynamic identities. Journal for Research in Mathematics Education, 44(1), 199-234. https://doi.org/10.5951/jresematheduc.44.1.0199

Turner, E., Gutiérrez, M. V., Simic-Muller, K., \& Díez-Palomar, J. (2009). "Everything is math in the whole world": Integrating critical and community knowledge in authentic mathematical investigations with elementary Latina/o students. Mathematical Thinking and Learning, 11(3), 136-157. https://doi.org/10.1080/10986060903013382

Vakil, S., McKinney de Royston, M., Nasir, N. S., \& Kirshner, B. (2016). Rethinking race and power in design-based research: reflections from the field. Cognition and Instruction, 34(3), 194-209. https://doi.org/10.1080/07370008.2016.1169817

van Dijk, T. A. (1991). Racism and the press. Routledge.

Vossoughi, S., Jackson, A., Chen, S., Roldan, W., \& Escudé, M. (2020). Embodied pathways and ethical trails: Studying learning in and through relational histories. Journal of the Learning Sciences, 29(2), 183-223. https://doi.org/10.1080/10508406.2019.1693380

Vygotsky, L.S. (1978). Mind in society: The development of higher psychological processes. Cambridge University Press.

Wortham, S. (2006). Learning identity: The joint emergence of social identification and academic learning. Cambridge University Press.

Zahner, W., \& Moschkovich, J. (2011). Bilingual students using two languages during peer mathematics discussions: Que significa? Estudiantes bilingues usando dos idiomas en sus discusiones matematicas: What does it mean? In K. Téllez \& J. Moschkovich (Eds.), Latinos/as and mathematics education: Research on learning and teaching in classrooms and communities. Information Age. 


\section{Appendix A}

Transcription Conventions (adopted from Hepburn \& Bolden, 2013 and the

only conventions relevant to the transcripts introduced in this article)

Temporal and sequential relationships

\begin{tabular}{|ll|}
\hline[ & point of overlap onset \\
$=$ & point of overlap offset \\
$(0.0)$ & latching utterances (no gap between lines) \\
$()$. & lapsed time in seconds \\
\hline
\end{tabular}

Speech delivery and intonation

\begin{tabular}{|ll|}
\hline$?$ & falling intonation \\
underlining & rising intonation (not necessarily interrogatives) \\
$><$ & slightly rising intonation and a very short pause \\
$<>$ & rushed or compressed speech \\
$:$ & slowed down speech \\
$\circ \circ \circ \circ$ & prolongation \\
$(())$ & whispering \\
\hline
\end{tabular}


Takeuchi, M.A. (2020). Geopolitical configuration of identities and learning: Othering through the institutionalized categorization of "English language learners. Cognition and Instruction. Advance online publication https://doi.org/10.1080/07370008.2020.1825438 